Maciej Kokoszko (Łódź)

Jolanta Dybała (Piotrków Trybunalski)

\title{
Medical SCience of Milk InCluded in Celsus' Treatise De medicina
}

\begin{abstract}
$\mathrm{M}$ ilk has always been a very significant food product in the Mediterranean ${ }^{1}$ (but also in other regions of the ancient world ${ }^{2}$ ). Thus, it comes as no surprise that ancient and Byzantine physicians devoted their research to this subject ${ }^{3}$. It is commonly believed that fresh milk was quite rare in everyday diet of those times, whereas its derivative - namely cheese - was consumed much more frequently. This general production-consumption pattern survived the Antiquity and was equally characteristic of the early Middle Ages ${ }^{4}$.
\end{abstract}

\footnotetext{
${ }^{1}$ For the areas initially untouched by the Greek culture, and later by the Roman culture, cf. E. BREsCIANI, Nourritures et boissons de l'Égypte ancienne, [in:] Histoire de l'alimentation, ed. J.-L. FlanDrin, M. Montanari, Paris 1996, p. 63, 65, 67; J. Soler, Les raisons de la Bible: règles alimentaires hébraïques, [in:] Histoire..., p. 73-74, 79; A. Spanò Giammellaro, Les Phéniciens et les Carthaginois, [in:] Histoire..., p. 91, 96 etc. For the Greco-Roman area of the Mediterranean basin, cf. M.-C. AMOuretti, Villes et campagnes grecques, [in:] Histoire..., p. 138, 143; J.P. Alcock, Milk and its Products in Ancient Rome, [in:] Milk. Beyond the Dairy. Proceedings of the Oxford Symposium on Food and Cookery 1999, ed. H. WALker, Totnes 2000, p. 31-38; C.A. DÉRY, Milk and Dairy Products in the Roman Period, [in:] Milk..., p. 117-125; A. Dalby, Food in the Ancient World from A to Z, London-New York 2003, p. 217-218 etc.

${ }^{2}$ M. Stol, Milk, Butter and Cheese, BSA 7, 1993, p. 99-113; N. BAtmanglij, Milk and its By-products in Ancient Persia and Modern Iran, [in:] Milk..., p. 64-73 etc.

${ }^{3}$ Medical interest in milk can be found already in Corpus Hippocraticum - K. DeICHgRëвeR, Zur Milchteratpie der Hippokratiker (Epid. VII), [in:] Medizin-Geschichte in unsere Zeit. Festgabe E. Heischkel-Artel und W. Artel, ed. H.H. Eulner, Stuttgart 1971, p. 36-53; M. Chrone, 'H $\pi \alpha v i \delta \alpha$

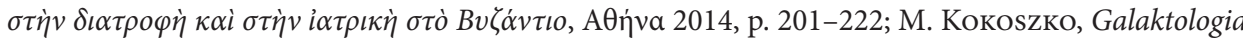
terapeutyczna ( $\gamma \alpha \lambda \alpha \kappa \tau o \lambda$ oүí i $\left.\alpha \tau \rho \iota \eta^{\prime}\right)$ Galena zawarta $w$ De simplicium medicamentorum temperamentis ac facultatibus, PNH 14, 2, 2015, p. 5-23. On application of milk in folk medicie, cf. M. АвDALla, Milk and its Uses in Assyrian Folklore, [in:] Milk..., p. 9-18, especially 11-13.

${ }^{4}$ C. Perry, Medieval Arab Dairy Products, [in:] Milk..., p. 275-277; I. Anagnostakis, C. Angelidi,

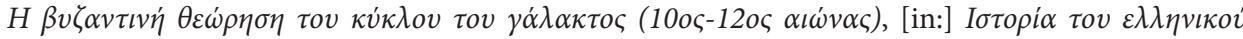

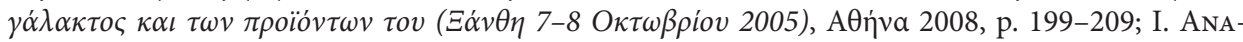

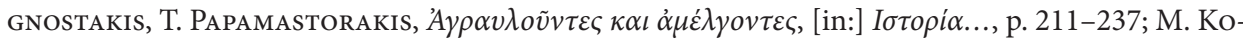
KoszKo, Smaki Konstantynopola, [in:] Konstantynopol - Nowy Rzym. Miasto i ludzie w okresie wczesnobizantyńskim, ed. M.J. LeszKa, T. WolińsKa, Warszawa 2011, p. 487-489, 560-562; IDEM, Rola nabiału w diecie późnego antyku i wczesnego Bizancjum (IV-VII w.), ZW 16, 2011, p. 8-28. Milk was
} 
What is more, milk also played a certain role as far as the cult is concerned ${ }^{5}$.

The present dissertation is not devoted to milk as such, but to therapeutic galac-

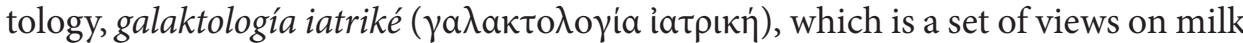
contained in the Latin work De medicina composed by a Roman encyclopaedist ${ }^{6}$ called Celsus (also known as Aulus Cornelius Celsus [Aulus Cornelius Celsus]), who compiled a work consisting of at least 26 books $^{7}$ during the reign of emperor Tiberius (14-37 AD). Only 8 books survived to this day, all of them devoted to medicine ${ }^{8}$.

From the point of view of our discussion it is important that in his narration, the author of De medicina often reflects on the proper diet of the readers of his treatise. He compares medicine to farming already in the introduction to his work, arguing that the former provides people with health, while the latter one supplies food $^{9}$. Diet is a capacious term for this Roman author, as he uses it to refer to a lifestyle in general, i.e. a whole set of activities practiced by human beings in their natural environment. This issue was dealt with by the branch of medicine called

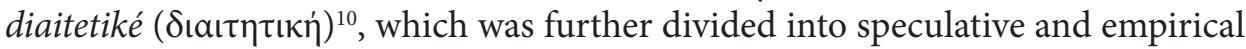
dietetics ${ }^{11}$. Food plays a significant role in this concept, as both the amount and type of food have a significant influence on our health ${ }^{12}$.

also generally allowed for alimentary uses of the Christian clergy - B. CASEAU, Nourritures terrestres, nourritures célestes. la culture alimentaire à Byzance, Paris 2015, p. 83 (though it was excluded from diet of all the faithful on certain days - p. 187-188).

${ }^{5}$ K. Wy hs, Die Milch im Kultus der Griechen and Römer, Giessen 1914, passim; C. Grottanelli, La viande et ses rites, [in:] Histoire..., p. 122.

${ }^{6}$ Celsus was certainly an amateur, not a professional in medicine - V. Nutton, Ancient Medicine, London-New York 2013, p. 5. However, according to Dioscorides ( $\varphi \iota \lambda \iota \alpha \tau \rho o \tilde{v} v \varepsilon \varsigma$ - Pedanii Dioscuridis Anazarbei de materia medica, V, 19, 3, 2, [in:] Pedanii Dioscuridis Anazarbei de materia medica libri quinque, ed. M. Wellmann, vol. I-III, Berlin 1907-1914 [cetera: Dioscorides, De materia

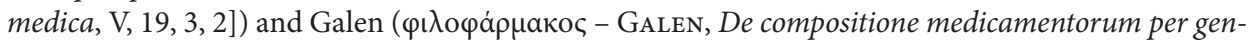
era libri VIII, 636, 2, [in:] Claudii Galeni opera omnia, ed. C.G. KüHN, vol. XIII, Lipsiae 1827), in the Roman world he was not the only one of this kind. Recently, Ido Israelowich acknowledged the phenomenon of general public interest in medicine in the times of the Empire (Patients and Healers in the High Roman Empire, Baltimore 2015, p. 73). Also cf. C.F. Schultze, Aulus Cornelius Celsus - Arzt oder Laie? Autor, Konzept und Adressaten der De medicina libri octo, Trier 1999, passim.

${ }^{7}$ Originally, his works contained not only information about medicine, but also about agriculture and animal husbandry, rhetoric, military art, philosophy and law.

${ }^{8}$ About Celsus and his works, e.g., cf. F. Marx, Prolegomena, [in:] A. Cornelii Celsi quae supersunt, ed. F. Marx, Lipsiae-Berlini 1915, p. I-XXV; C.M. Oser-Grote, Celsus, [in:] Antike Medizin. Ein Lexikon, ed. K.-H. Leven, München 2005, col. 189-191 etc.

${ }^{9}$ A. Cornelii Celsi quae supersunt, I, Prooemium, 1, ed. F. Marx, Lipsiae-Berlini 1915 (cetera: Celsus, De medicina).

${ }^{10}$ Celsus, De medicina, I, Prooemium, 9.

${ }^{11}$ Celsus, De medicina, I, Prooemium, 11.

${ }^{12}$ The issue of right proportion in terms of food and drink - CELsus, De medicina, I, 2, 8-10. 
It comes as no surprise then that the most important types of food were described by Celsus in De medicina (in a more or less systematic way) both in terms of their nutritional and therapeutic functions. We can infer from the narration that in the author's opinion, the latter was immanently connected with the former. Such a view was a reflection of a traditional doctrine adopted by the Greek medicine, on whose accomplishments Celsus based his work. Celsus mentions many authorities, most of them Greek. The very word "Greeks", meaning "Hellenic physicians", is used a few dozen times in his output ${ }^{13}$. Nota bene, his knowledge of Greek medical thought is also revealed in the terminology used by him, which is a Latinised jargon of the Asclepiads ${ }^{14}$.

Having discussed the general aspects of Celsus' work, let us now focus on his detailed knowledge of milk and its derivatives. In order to learn about it, it is necessary to look at book II of De medicina, which contains an interesting fragment concerning procedures of cleansing the gastrointestinal tract. According to the author, in order to achieve this, enemas were used or drugs of two kinds were administered to patients, namely those that provoke cleansing through excretion and those that induce vomiting. Milk was enumerated in the first class of the second group, or, to be precise, among substances facilitating excretion. Such a laxative effect was to be achieved by animal milk, and Celsus specified three types of milk here, namely donkey's, cow's and goat's milk. His narration also reveals that people would make this remedy more effective by adding some salt to it. Moreover, we learn from Celsus that milk is not a homogenous substance, but a complex one, and it is whey (referred to as serum, ópó in Greek) ${ }^{15}$ that is the active element in the cleansing procedure. Celsus also gave us some clues with regard to the way of separating curd from the remaining liquid. According to the text,

\footnotetext{
${ }^{13}$ Cf. W. Deuse, Celsus im Prooemium von "De medicina": Römische Aneignung griechischer Wissenschaft, [in:] ANRW, ed. W. HAAsE, T. II, Bd. 37, 1, Berlin-New York 1993, p. 819-841.

${ }^{14}$ D.R. Langslow, Celsus and the Makings of a Latin Medical Terminology, [in:] La Médecine de Celse. Aspects historiques, scientifique, and litéraires, Mémoires du Centre Jean Palerne, vol. XIII, ed. G. Sabbah, P. Mudry, Saint-Étienne 1994, p. 297-318; S. Sconocchia, Aspetti della lingua di Celso, [in:] La Médecine..., p. 281-296.

${ }^{15}$ E.g., cf. Galeni De alimentorum facultatibus libri III, 684, 16 - 685, 6, [in:] Claudii Galeni opera omnia, ed. D.C.G. KüHN, vol. VI, Lipsiae 1823 (cetera: GALEN, De alimentorum facultatibus). About the life and work of Galen, e.g. cf. V. Nutton, Galen and the Traveller's Fare, [in:] Food in Antiquity, ed. J. Wilkins, D. Harvey, M. Dobson, Exeter 1999, p. 359-370; IDem, Ancient..., p. 222-235; R.J. Hankinson, The Man and His Work, [in:] The Cambridge Companion to Galen, ed. IDEM, Cambridge 2008, p. 1-33; M. Koкoszko, K. Jagusiak, Z. Rzeźnicka, Wstęp. Wiedza o pokarmach $w$ źródłach medycznych. Dietetyka, farmakologia i sztuka kulinarna, [in:] IIDEm, Dietetyka i sztuka kulinarna antyku i wczesnego Bizancjum (II-VII w.), part I, Zboża i produkty zbożowe w źródłach medycznych antyku i wczesnego Bizancjum, Łódź 2014, p. 8-16; IIDEM, Introduction. Knowledge of Foods in Medical Sources. Dietetics, Pharmacology and Culinary Art, [in:] IIDEM, Cereals of Antiquity and Early Byzantine Times. Wheat and Barley in Medical Sources (Second to Seventh Centuries AD), transl. K. Wodarczyk, M. Zakrzewski, M. ZytKa, Łódź 2014, p. 8-19.
} 
it was a result of heating milk, which caused coagulation of protein (not used during this procedure) and consequent separation of the liquid which was subsequently administered to patients ${ }^{16}$. The author also concluded that the cleansing procedure with the use of milk was considered safer than the use of other (more radical) remedies, so it is a good choice for patients with fever, especially considering the fact that whey not only softens the intestines, but also provides valuable nourishment ${ }^{17}$. This passage has a great educational value for a number of important clues, as it places milk and milk-derived products among therapeutic substances (namely, laxatives), indicates the methods of processing such substances, and also provides the readers with interesting details as regards the dietary and pharmacological characteristics of dairy foods.

Let us start with some basic issues. According to Celsus, milk is a combination of at least two elements which make this product a nutrient with additional properties that can be used for therapeutic purposes. It is also worth noticing that although the discussed fragment lacks precise description of milk or its components, the author in fact refers to a medical theory which established and adopted such characteristics. Celsus indicates that curd shares certain specific nutritional values with whey and that both of them contribute to the evaluation of milk as nourishing substance. We know it because the author recommends the latter as far as cleansing the digestive tract is concerned, so it can be assumed that curd has a different effect with regard to stimulating the digestive system to excrete. Therefore, it seems that Celsus suggested that it was considered by the medical specialists to be the reason for constipation. Furthermore, it should also be concluded that cheese made of curd had similar properties, as it was a derivative of the latter one. The technology described by the author of De medicina (which was supposed to show the way of obtaining whey) was in fact also a method of obtaining raw material used to produce cheese. Moreover, we may conclude on the basis of Celsus' narration that (from the point of view of pharmacological properties) cheese could not be used as a laxative, because it acquired the properties of the curd. Nota bene, one of the elements of milk was not mentioned within the analysed part of the text, but surely Celsus was aware of its existence. It was fat, used to produce butter (buturum/butyrum in Latin, ßov́tupov in Greek). Butter, in turn, was often mentioned as one of therapeutic remedies and it was even described as an active substance, which means that it was in the scope of interest of pharmacology. Therefore, there is no doubt that it was addressed to by the theory acknowledged by De medicina. The analysed fragment also suggests that milk itself (as a mixture) could change its properties depending on the amount of constituents. The quantity

\footnotetext{
${ }^{16}$ Analogical, though a more specific narration is for instance used by Oribasius, cf. Oribasii libri ad Eunapium, I, 9, 9, 1 - 12, 1, [in:] Oribasius synopsis ad Eustathium filium et libri ad Eunapium, ed. I. RAEDER, Lipsiae-Berolini 1926 (cetera: Oribasius, Libri ad Eunapium).

${ }^{17}$ Celsus, De medicina, II, 12, 1 a-c.
} 
of such elements was fully contingent on the type of milk (which is suggested by the remark about the possibility to obtain milk from various animals) and it could be modified through processing of milk. The therapeutic effect of milk could also be intensified with the use of excipients, for instance salt, as mentioned by Celsus ${ }^{18}$.

Far-reaching as the aforementioned conclusions may seem (in view of the general character of the analysed fragment of De medicina), they are fully confirmed in the part which discusses the role of food as a significant element of diet and which is in fact a catalogue of food groups listed according to a dominant property of a given product. It has to be indicated that medical literature of that time knows many such listings. Their fully-fledged form can be found in the works of Oribasius $^{19}$, and then of Aetius of Amida ${ }^{20}$ (and in the later treatises). We should also mention here that the dietetic characterizations composed by Celsus refer directly or indirectly to all the products mentioned here, however with the exception of butter. As we will see later, butter was characterized only from the point of view of its pharmacological properties, so it can be concluded that in the light of the medical theory adopted in De medicina it was mainly treated not as a foodstuff, but as a medicament. Such a position in the doctrine is a sign of its minimal participation in the consumption pattern of the Mediterranean world as known to Celsus and his authorities.

Let us now present Celsus' doctrines in order of appearance in his work. The author started with emphasising the high nutritious value of milk ${ }^{21}$, and he ascribed the same property to cheese, which is conclusively confirmed by the fact that he classified baked cereal foods with the addition of (animal fat, honey and) cheese as wholesome diet elements ${ }^{22}$. Celsus also claimed that milk and soft (mollis, meaning fresh) cheese are evaluated as diet elements belonging to the group of food with good juices (boni suci [alimenta] ${ }^{23}$, whereas old (vetus) cheese was classified as one of the foodstuffs characterised by harmful humours (mali suci [alimenta] $)^{24}$. This obviously presents Celsus as a person familiarised with the humoral theory (of some sort). Milk was also placed in the category of foodstuffs with gentle, i.e. non-pungent juices (lenes) ${ }^{25}$. Apart from that, it was also indicated that this drink thickens the phlegm (crassiorem pituitam facit) ${ }^{26}$. Moreover, milk and cheese of every kind were classified as food products that may disrupt the

\footnotetext{
${ }^{18}$ Salt intensified the laxative effect of milk.

${ }^{19}$ Firstly, in book III of Collectiones medicae, to be later included in Synopis ad Eustathium filium and in Libri ad Eunapium.

${ }^{20}$ Book II of Iatricorum libri.

${ }^{21}$ Celsus, De medicina, II, 18, 11.

${ }^{22}$ Celsus, De medicina, II, 18, 2.

${ }^{23}$ Celsus, De medicina, II, 20, 1.

${ }^{24}$ Celsus, De medicina, II, 21.

${ }^{25}$ Celsus, De medicina, II, 22, 2.

${ }^{26}$ Celsus, De medicina, II, 23.
} 
stomach (aliena stomacho) ${ }^{27}$, whereas milk and all kinds of edibles to which it was added, as well as all types of cheese were considered to be a part of a group of products that get acidified easily ${ }^{28}$ (faciliter intus corrupta) in the stomach ${ }^{29}$. Moreover, Celsus returned to the subject that he discussed in the first analysed fragment of his work by indicating that milk and food products containing milk improve intestinal peristalsis (alvum movent), and therefore stimulate excretion ${ }^{30}$. Eventually, we also find information that cheese with pungent flavour (whether due to its age or change of properties during transport ${ }^{31}$ or as a result of boiling it with honey or water and honey) causes constipation and slows down the activity of the digestive tract (astringit) ${ }^{32}$.

Selected dairy products also appear in another catalogue. They are present as elements of respective classes of pharmacologically active substances which are listed in book V of De medicina. The catalogue of the most significant medicament groups is opened by remedies that staunch bleeding ${ }^{33}$, and concluded by effective skin cleansing substances ${ }^{34}$. In total, there were sixteen classes of active substances enumerated by Celsus. In terms of the present discussion, it is important that even though milk and butter are present among listed medicaments, cheese and whey are not. The author does not explain the reasons for such absence in any way. It may be the case that the sources used by him did not specify these two products in the categories of our interest. Nota bene, the absence of these products does not mean that Celsus did not consider them useful for medical procedures were concerned. As it has already been explained, whey was an element of purgative diets and was referred to as lac. Cheese (also absent from the analysed list) was also taken into consideration in treatment of aphthous stomatitis, which means that it was used in the therapeutic method known to Celsus. However, such cases were rare, so this product was treated mainly as a foodstuff. It should be mentioned here that in later Greek medical sources cheese is invariably classified as phármakon. This may be proved by the testimonies to which we shall refer later in this paper ${ }^{35}$. However, a conclusion can be drawn that progress in this area took place later that the state of medicine as known to Celsus was formed ${ }^{36}$.

\footnotetext{
${ }^{27}$ Celsus, De medicina, II, 25, 1.

${ }^{28}$ Translation has been accepted on the basis of terminology from the Greek sources. Cf. relevant parts of the theory, as quoted from Oribasius.

${ }^{29}$ Celsus, De medicina, II, 28, 1.

${ }^{30}$ Celsus, De medicina, II, 29, 2.

${ }^{31}$ Duration of a journey was probably one of the factors contributing to the process of cheese maturing.

${ }^{32}$ Celsus, De medicina, II, 30, 2.

${ }^{33}$ Celsus, De medicina, V, 1.

${ }^{34}$ Celsus, De medicina, V, 16.

${ }^{35} \mathrm{Cf}$. later parts of this text.

${ }^{36}$ About the types and applications of cheese in cookery and medical procedures, cf. M. CHrone, 'H $\pi \alpha v i \delta \alpha \ldots$, p. 217-226.
} 
As far as information from De medicina is concerned, it has to be stated that milk is found among substances capable of dispersing harmful substances concentrated in any part of the body ${ }^{37}$. Moreover, it is listed among those medicaments that soothe irritation (together with zinc oxide, ivory etc.) ${ }^{38}$. Butter was also placed in two catalogues. First of all, we learn that it belongs to the group of medical substances causing tissue growth and filling the cavities that are formed as a result of ulcers (carnem alens; ulcus implens) ${ }^{39}$. Secondly, it is listed among the softening medicaments (molliens) ${ }^{40}$ that could eliminate tumorous calluses and swellings of all kinds. Interestingly enough, all effects of milk and butter listed above are confirmed by specific applications in treatments enumerated by Celsus. Therefore, we know that the theory to which he referred is both internally coherent and practically applicable.

Having concluded these considerations, it is necessary to pay attention to the fact that the characterizations of milk and dairy products with regard to their dietary properties and application as phármakon ( $\varphi \dot{\alpha} \rho \mu \kappa o v)$ are not an exclusive feature of De medicina, but they are regularly mentioned not only in medical works, such as De diaeta $I-I V^{41}$, works of Dioscorides ${ }^{42}$, extant fragments penned by Rufus of Ephesus ${ }^{43}$,

\footnotetext{
${ }^{37}$ Celsus, De medicina, V, 11. It can be effective as an anti-tumour substance. Cf. F.G. BRunNer, Pathologie und Therapie der Geschwülste in der antiken Medizin bei Celsus und Galen, Zurich 1977, passim.

${ }^{38}$ Celsus, De medicina, V, 13.

${ }^{39}$ Celsus, De medicina, V, 14.

${ }^{40}$ Celsus, De medicina, V, 15.

${ }^{41}$ Cf. milk - Hippocratis de diaeta, 41, 4-7, ed. R. Joly, S. ByL, Berlin 1984 (cetera: De diaeta I-IV); whey - De diaeta $I-I V, 42,20-22$; cheese - De diaeta $I-I V, 51,1-4$; milk fat (for butter) - De diaeta $I-I V, 51,3$.

${ }^{42}$ Dioscorides, De materia medica, II, 70, 1, 1 - 72, 3, 9 (milk - II, 70, 1, 1 - 3, 5; II, 70, 5, 1 - 6, 12; whey - II, 70, 3, 6 - 4, 10; cheese - II, 71, 1, 1-9; butter - II, 72, 1, 1-2, 8). About Dioscorides, for instance cf. M. Wellmann, Dioscorides, [in:] RE, Bd. V, Stuttgart 1905, col. 1131-1142; J.M. Riddle, Dioscurides on Pharmacy and Medicine, Austin 1985, passim; M. Koкоszko, Ryby i ich znaczenie w życiu codziennym ludzi późnego antyku i Bizancjum (IV-VII w.), Łódź 2005, p. 12; M. STAMatu, Dioscorides, [in:] Antike Medizin..., col. 227-229; V. Nutton, Ancient..., p. 174-177; R.A. Gabriel, Man and Wound in the Ancient World. A History of Military Medicine from Sumer to the Fall of Constantinople, Washington 2012, p. 174-175.

${ }^{43}$ His works have not been preserved as a whole, but they are cited by the later Asclepiads. Cf. milk - Rufus d'Ephese, De renum et vesicae morbis, II, 19, 1 - 21, 7, [in:] Oeuvres de Rufus d'Ephese, ed. C. Daremberg, C.E. Ruelle, Paris 1879; Rufus D'Ephese, De satyriasmo et gonorrhoea, 28, 5, [in:] Oeuvres de Rufus d'Ephese, ed. C. Daremberg, C.E. Ruelle, Paris 1879 (cetera: Rufus of Ephesus, De satyriasmo et gonorrhoea); Oribasii collectionum medicarum reliquiae, II, 61, 1, 1 - 10, 2, ed. I. RAeder, vol. I-IV, Lipsiae-Berolini 1928-1933 (cetera: Oribasius, Collectiones medicae); Oribasii synopsis ad Eustathium filium, I, 40, 1, 1 - 6, 3, [in:] Oribasius synopsis ad Eustathium filium et libri ad Eunapium, ed. I. RAEDER, Lipsiae-Berolini 1926 (cetera: OribAsius, Synopsis ad Eustathium filium); Aetii Amideni libri medicinales I-VIII, II, 86, 1 - 87, 15, ed. A. OlIVIERI, Lipsiae-Berolini 1935-1950 (cetera: Aetius of Amida, Iatricorum libri); cheese - Rufus of Ephesus, De satyriasmo et gonorrhoea, 28, 5. About Rufus of Ephesus, cf. H. Gossen, Rufus (18), [in:] RE, 2. Reihe, Bd. I, 1,
} 


\section{Galen $^{44}$, Oribasius ${ }^{45}$, Aetius of Amida ${ }^{46}$ and Paul of Aegina ${ }^{47}$, but also in Historia}

Stuttgart 1914, col. 1207-1212; A. Sideras, Einleitung, [in:] Rufus Ephesius, De renum et vesicae morbis, ed. A. Sideras, Berlin 1977, p. 58-69; IDEM, Rufus von Ephesos und sein Werk im Rahmen der antiken Medizin, [in:] ANRW, ed. H. Temporini, W. HaAse, T. II, Bd. 37, 2, Berlin-New York 1994, p. 1077-1253; H. Thomssen, C. Рrobst, Die Medizin des Rufus von Ephesos, [in:] ANRW, ed. H. Temporini, W. HaAse, T. II, Bd. 37, 2, Berlin-New York 1994, p. 1254-1292; S. Ihm, Rufus v. Ephesos, [in:] Antike Medizin..., col. 759-760.

${ }^{44}$ Milk and dairy products were characterized in many Galen's works. For the widest description of their dietary and pharmacological properties, cf. GALEN, De alimentorum facultatibus, 681, 11 -699, 9 (milk, whey - 681, 11 - 689, 7; cheese - 696, 7 - 699, 9; butter - 683, 11 - 684, 6; Galeni de simplicium medicamentorum temperamentis ac facultatibus libri XI, 263, 12 - 269, 15, vol. XII, [in:] Claudii Galeni opera omnia, ed. D.C.G. KüHN, vol. XI-XII, Lipsiae 1826-1827 (cetera: Galen, De simplicium medicamentorum temperamentis ac facultatibus) (milk - 263, 12 - 269, 15, vol. XII; whey - 266, 7 - 269, 15, vol. XII; cheese - 269, 16 - 272, 8, vol. XII; butter - 272, 9 - 273, 18, vol. XII). ${ }^{45}$ Information about them can be found both in Collectiones medicae and in Synopsis ad Eustathium filium and in Libri ad Eunapium. The most extensive fragments of this kind are included in the first title. Cf. Oribasius, Collectiones medicae, II, 59, 1, 1 - 14, 5 (milk - II, 59, 1, 1 - 11, 1; XV, 2, 1, 1 - 3, 1; whey - II, 59, 3, 2; XV, 2, 3, 1 - 5, 1; cheese - II, 59, 11, 1 - 14, 5; XV, 2, 5, 1; butter - XI, $\beta, 14$, 1-9; XV, $2,8,1-5)$. It is important to remember that, apart from the descriptive characteristics, all the products were included in book III of Collectiones medicae, in the list of products presented according to their most prominent dietary property. Cf. below. About the life and works of Oribasius cf. B. BALDwin, The Career of Oribasius, AClas 18, 1975, p. 85-97; M. GRAnt, Oribasios and Medical Dietetics or

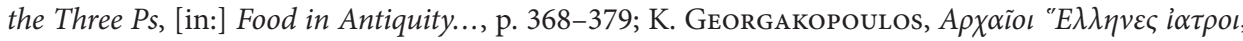
AӨj́va 1998, p. 62-63; R. De Lucia, Oreibasios v. Pergamon, [in:] Antike Medizin..., col. 660-661; idem, Oribasio di Pergamo, [in:] A. Garzya, R. de Lucia, A. Guardasole, A.M. Ieraci Bio, M. Lamagna, R. Romano, Medici byzantini. Oribasio di Pergamon. Aezio d' Amida. Alessandro di Tralle. Paolo d'Egina. Leone medico, Torino 2006, p. 21-29; V. Nutton, Ancient..., p. 295-296; K. JAGUSIAK, M. Kокоszко, Życie i kariera Orybazjusza w świetle relacji źródłowych, PNH 10, 2011, p. 5-21; IIDEM., Pisma Orybazjusza jako źródło informacji o pożywieniu ludzi w późnym Cesarstwie Rzymskim, VP 33, 2013, p. 339-357; M. Kокоszko, K. Jagusiak, Z. Rzeźnicka, Wstęp. Wiedza o..., p. 16-20; IIDEM, Introduction. Knowledge of Foods..., p. 19-22.

${ }^{46}$ Milk - Aetius of AmidA, Iatricorum libri, II, 86, 1 - 95, 28; II, 97, 1-11; whey - II, 95, 28-58; cheese - II, 101, 1 - 103, 7; butter - II, 104, 1-13. In Iatricorum libri we can find the same dietary and pharmacological categories, which were included in book III of Collectiones medicae. They are part of book II of the medical encyclopedia composed by Aetius of Amida. Cf. below. About the life and works of Aetius of Amida cf. H. Lehmann, Au Aëtius Amidenus, Sar 23, 1930, p. 205-206; P. Diepgen, Zur Frauenheilkunde im byznatinischen Kulturkreis des Mittelalters. Akademie der Wissenschaften und der Literatur. Abhandlungen der Geistes- und Sozialwissenschaften Klasse, Wiesbaden 1950, p. 4-5; H. Hunger, Die hochsprachliche profane Literatur der Byzantiner, Bd. I, München 1978, p. 294-296; V. Nutton, From Galen to Alexander. Aspects of Medicine and Medical Practice in Late Antiquity, DOP 38, 1984, p. 1-14; J. Scarborough, Early Byzantine Pharmacology, DOP 38,

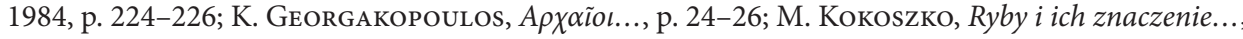
p. 9-10; A. Garzya, Aetios v. Amida, [in:] Antike Medizin..., col. 19-20; V. Nutton, Ancient..., p. 295; M. Кокоszko, K. Jagusiak, Z. Rzeźnicka, Wstęp. Wiedza o..., p. 20-21; IIDEM, Introduction. Knowledge of Foods..., p. 22-24.

${ }^{47} \mathrm{Cf}$. the general characteristics of milk - Paulus Aegineta, VII, 3, 3, 2-11, ed. I.L. HeIBERG, vol. I-II, Lipsiae-Berolini 1921-1924 (cetera: Paul of Aegina, Epitome); whey - VII, 3, 3, 2-5; cheese - VII, 3, 19, 101-95; butter - VII, 3, 2, 63-66. About Paul of Aegina, cf. H. Diller, Paulos (23), [in:] RE, 
naturalis by Pliny ${ }^{48}$. This is a clear sign that milk was considered to be significant from the medical point of view and was as such very interesting both for the Asclepiads and for general public. It should be added here that considering all these facts, De medicina appears as a typical work, not an exceptional one. Details contained in it are simply a testimony (recorded in the first half of the $1^{\text {st }}$ century) of the evolution of the doctrine that was already present in De Diaeta I-IV and later developed by the most prominent physicians.

As we read the works of Greek medical specialists, we can clearly see that the assumptions of dietetic and pharmacological galactology presented in De medicina were not in contradiction to the theories adopted by other medical authors. Such teachings appear to be rather invariable. In order to show the doctrinal stability of galactology, it is enough to compare the already presented classifications of milk and milk-derived products contained in Celsus' De medicina with medical and pharmacological descriptions presented in Oribasius' treatises. The latter writings, although compiled as late as in the late $4^{\text {th }}$ century, were by assumption a selection of the most important views on this subject in the medical theory (and practice) going back to the times of Hippocrates. Accordingly, we read that Oribasius included freshly obtained milk (coming from a healthy animal) as a foodstuff generating good bodily juices ${ }^{49}$ and considered it to be nutritious (adding that thick $\gamma \dot{\alpha} \lambda \alpha$ tends to give more nourishment than its watery version) ${ }^{50}$, and that is why eventually stimulating creation of viscous humours ${ }^{51}$. The physician also warned his readers that fresh milk could adversely affect the stomach. He explained that in the case of a cold one, milk would easily acidify, whereas

Bd. XVIII, 4, Stuttgart 1949, col. 2386-2397; P. Pormann, Paulos v. Aigina, [in:] Antike Medizin..., col. 681-682; IDEM, The Oriental Tradition of Paul of Aegina's Pragmateia, Leiden 2004, passim; M. Kokoszko, K. Jagusiak, Z. Rzeźnicka, Wstęp. Wiedza..., p. 21-22; IIDem, Introduction. Knowledge of Foods..., p. 24.

${ }^{48}$ Pliny, Natural History, transl. H. Rackham, W.H.S. Jones, D.E. EichHolz, vol. VIII, London-Cambridge, Mass. 1963 (cetera: Pliny, Historia naturalis) (milk - XXVIII, 33, 123 - 130; whey - XXVIII, 33, 126-127; cheese - XXVIII, 34, 131-132; butter - XXVIII, 35, 133-134). About Pliny and the aspects of his output that are interesting to us here, cf. W. Kroll, Plinius (5), [in:] RE, Bd. XXI, 1, Stuttgart 1951, col. 271-439; J.F. Healy, Pliny the Elder on Science and Technology, Oxford 2000; I. MiкоєајсZyк, Rzymska literatura agronomiczna, Toruń 2004, passim.

${ }^{49}$ Oribasius, Collectiones medicae, III, 15, 1, 1 - 22, 3 (milk - III, 15, 1, 1 - 2, 1); Oribasius, Libri ad Eunapium, I, 32, 1, 1 - 15, 3 (milk - I, 32, 1, 1-2); Oribasıus, Synopsis ad Eustathium filium, IV, 14, 1, 1 - 21, 3 (milk - IV, 14, 1, 1-2).

${ }^{50}$ Oribasius, Collectiones medicae, III, 13, 1, 1 - 13, 2 (thick milk - III, 13, 4, 1; thin milk - III, 13, 4, 1 - 5, 1); Oribasius, Libri ad Eunapium, I, 29, 1, 1 - 15, 2 (thick milk - I, 29, 5, 1; thin milk - I, 29, 5, 1 - 6, 1); Oribasius, Synopsis ad Eustathium filium, IV, 12, 1, 1 - 15, 2 (thick milk and thin milk - IV, 12, 5, 1-6,1).

${ }^{51}$ Oribasius, Collectiones medicae, III, 3, 1, 1 - 7, 3 (boiled down milk - III, 3, 6, 4); OrIBasius, Libri ad Eunapium, I, 19, 1, 1 - 5, 4 (boiled down milk - I, 19, 4, 5); Oribasıus, Synopsis ad Eustathium filium, IV, 2, 1, 1-5, 3 (boiled down milk - IV, 2, 4, 5). 
in a warm organ the process of concoction taking place therein could lead to its emitting "greasy" fumes (whose features were similar to those characterizing the smoke soaring from offerings burnt in the altar) ${ }^{52}$. Moreover, Oribasius noted that milk could cause flatulence ${ }^{53}$ and bring about headaches ${ }^{54}$. On top of this, the author remarked that consumption of milk in large quantities was to blame for the formation of kidney stones in the urinary tract) as well as for incidence of blockages in the liver ${ }^{55}$. Apart from this, Oribasius classified milk as one of the foodstuffs which slowed down the activity of the alimentary tract and explained that boiled milk had stronger properties of the sort, as thermal treatment reduced its content of whey ${ }^{56}$. No wonder that the medical doctor included the latter in the enumeration of substances with laxative properties, and added that they could be even stronger if honey or salt is mixed with milk $\mathrm{k}^{57}$. As a result, it is logical that whey was similarly listed as a foodstuff belonging to the class of edibles capable of diluting thick juices, removing blockages and cleanse the bowels ${ }^{58}$. Moreover, it was included in the group of cleansing substances ${ }^{59}$ and also in the list of those with a moderate warming action ${ }^{60}$.

\footnotetext{
${ }^{52}$ It is also harmful for those in fever. For various versions of this argument, cf. OrIBAsius, Collectiones medicae, III, 20, 1, 1 - 10, 2 (milk - III, 20, 5, 1 - 7, 1); OrIBasius, Libri ad Eunapium, I, 37, 1, 1 - 8, 2 (milk - I, 37, 4, 1 - 6, 1); Oribasius, Synopsis ad Eustathium filium, IV, 19, 1, 1 - 10, 2 (milk - IV, 19, 5, 1-7, 1).

${ }^{53}$ Oribasius, Collectiones medicae, III, 23, 1, 1 - 9, 4 (milk - III, 23, 7, 1); Oribasius, Libri ad Eunapium, I, 39, 1, 1 - 7, 1 (milk - I, 39, 4, 1 - 5, 1); Oribasius, Synopsis ad Eustathium filium, IV, 22, 1, 1 - 10, 1 (milk - IV, 22, 7, 1-8, 1).

${ }^{54}$ Oribasius, Collectiones medicae, III, 21, 1, 1- 6, 2 (milk - III, 21, 5, 1 - 6, 1); Oribasius, Synopsis ad Eustathium filium, IV, 20, 1, 1 - 4, 2 (milk - IV, 20, 3, 1).

${ }_{55}$ Oribasius, Collectiones medicae, III, 25, 1, 1 - 8, 2 (milk - III, 25, 1, 1-5); Oribasius, Libri ad Eunapium, I, 41, 1, 1 - 7, 2 (milk - I, 41, 1, 1 - 2, 1); OrIBAsIUs, Synopsis ad Eustathium filium, IV, 24, 1, 1 - 8, 2 (milk - IV, 24, 1, 1-2, 1).

${ }^{56}$ Oribasius, Collectiones medicae, III, 30, 1, 1 - 9, 3 (milk - III, 30, 4, 1-2); Oribasius, Synopsis ad Eustathium filium, IV, 30, 1, 1 - 13, 3 (milk - IV, 30, 5, 1).

${ }^{57}$ In the same fragment, he mentioned that milk with a larger amount of ópóc had the same effect. Cf. Oribasius, Collectiones medicae, III, 29, 1, 1 - 22, 2 (milk - III, 29, 8, 1 - 10, 1); Oribasius, Libri ad Eunapium, I, 45, 1, 1 - 17, 1 (milk - I, 45, 8, 1 - 10, 1); Oribasıus, Synopsis ad Eustathium filium, IV, 28, 1, 1 - 27, 2 (milk - IV, 28, 9, 1 - 12, 1).

${ }^{58}$ Oribasius, Collectiones medicae, III, 24, 1, 1 - 16, 7 (whey - III, 24, 7, 1 - 8, 1); Oribasius, Libri ad Eunapium, I, 40, 1, 1 - 14, 7 (whey - I, 40, 6, 1 - 7, 1); OrIBAsIUs, Synopsis ad Eustathium filium, IV, $23,1,1-16,7$ (whey - IV, 23, 7, 1). Whey as a product that diluted excessively thick juices - ORIBAsius, Collectiones medicae, III, 2, 1, 1 - 26, 2 (whey - III, 2, 26, 1); Oribasius, Libri ad Eunapium, II, 15, 1, 1-26 (whey - II, 15, 1, 4); Oribasius, Synopsis ad Eustathium filium, IV, 1, 1, 1 - 22, 3 (whey - IV, 1, 22, 1-2).

${ }^{59}$ Oribasius, Collectiones medicae, XIV, 48, 1, 1-42 (whey - XIV, 48, 1, 4); Oribasius, Libri ad Eunapium, II, 15, 1, 1-26 (whey - II, 15, 1, 4); OrIbasius, Synopsis ad Eustathium filium, II, 34, 1, 1-19 (whey - II, 34, 1, 3).

${ }^{60}$ Oribasius, Collectiones medicae, XIV, 15, 1, 1-5 (whey - XIV, 15, 1, 5); OrIBasius, Synopsis ad Eustathium filium, II, 3, 1, 1-3 (whey - II, 3, 1, 3).
} 
As for cheese, Oribasius observed that it could have various properties with regard to its freshness and thermal treatment. He remarked that soft types of cheese (probably the fresh ones) could lead to generation of black bile ${ }^{61}$, whereas old cheese contributed to production of what he termed "harmful humours" 62 . He considered both these kinds to be hard to digest, but also remarked that matured cheese was particularly unhealthy in this respect, whereas fresh varieties were easier to concoct in the stomach ${ }^{63}$. For the same reason the physician included the product in the class of the edibles able to generate thick juices, adding that fresh cheeses were less effective in this respect ${ }^{64}$. The latter variety (with an addition of honey) was also classified as a foodstuff which could accelerate the action of the alimentary tract ${ }^{65}$. Apart from this, Oribasius noted that consumption of old cheese resulted in warming up the body and induced thirst ${ }^{66}$, whereas the fresh one had a limited cooling influence ${ }^{67}$. He also noted down that consumption of the foodstuff could bring about flatulence ${ }^{68}$ and is likely to contribute to generation of raw juices ${ }^{69}$. Last but not least, he included fresh cheese of the

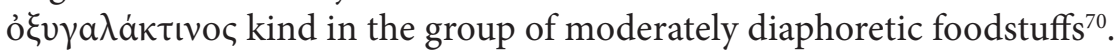

When it comes to butter, Oribasius did not omit it in his catalogues either. On the basis of his teachings, one can come to the conclusion that he fully followed

\footnotetext{
${ }^{61}$ Oribasius, Collectiones medicae, III, 9, 1, 1 - 2, 5 (cheese - III, 9, 2, 4); Oribasius, Libri ad Eunapium, I, 25, 1, 1 - 2, 4 (cheese - I, 25, 2, 3); Oribasius, Synopsis ad Eustathium filium, IV, 8, 1, 1 - 2, 5 (cheese - IV, 8, 2, 4).

${ }^{62}$ Oribasius, Collectiones medicae, III, 16, 1, 1 - 18, 3 (cheese - III, 16, 7, 3); Oribasius, Libri ad Eunapium, I, 33, 1, 1-16, 4 (cheese - I, 33, 5, 2 an obvious error on the part of the editor, who instead

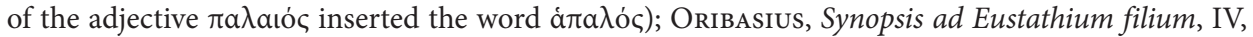
$15,1,1-18,4$ (cheese - IV, 15, 6, 2).

${ }^{63}$ Oribasius, Collectiones medicae, III, 18, 1, 1 - 13, 1 (cheese - III, 18, 7, 2 - 8, 1); Oribasius, Libri ad Eunapium, I, 35, 1, 1 - 8, 2 (cheese - I, 35, 5, 2); Oribasius, Synopsis ad Eustathium filium, IV, 17, $1,1-12,1$ (cheese - IV, 17, 5, 2-6,1).

${ }^{64}$ Oribasius, Collectiones medicae III, 3, 1, 1- 7, 3 (cheese - III, 3, 6, 4-5); Oribasius, Libri ad Eunapium, I, 19, 1, 1 - 5, 4 (cheese - I, 19, 4, 5-6); Oribasius, Synopsis ad Eustathium filium, IV, 2, 1, 1 $-5,3$ (cheese - IV, 2, 4, 5-6).

${ }^{65}$ Oribasius, Collectiones medicae, III, 29, 1, 1 - 22, 2 (cheese - III, 29, 12, 2); Oribasius, Libri ad Eunapium, I, 45, 1, 1 - 17, 1 (cheese - I, 45, 11, 3); Oribasıus, Synopsis ad Eustathium filium, IV, 28, $1,1-27,2$ (cheese - IV, 28, 15, 2).

${ }^{66}$ Oribasius, Collectiones medicae, III, 31, 1, 1 - 8, 4 (cheese - III, 31, 7, 1 - 8, 1); Oribasius, Libri ad Eunapium, I, 47, 1, 1-9 (cheese - I, 47, 1, 5); Oribasius, Synopsis ad Eustathium filium, IV, 31, 1, $1-8,4$ (cheese - IV, 31, 7, $1-8,1$ ).

${ }^{67}$ Oribasius, Collectiones medicae, XIV, 19, 1, 1-22 (cheese - XIV, 19, 1, 21-22); Oribasius, Libri ad Eunapium, II, 4, 1, 1 - 4, 2 (cheese - II, 4, 1, 14 - 2, 1); OrIbasius, Synopsis ad Eustathium filium, II, 7, 1, 1-14, (cheese - II, 7, 1, 13-14).

${ }^{68}$ Oribasius, Synopsis ad Eustathium filium, IV, 22, 1, 1 - 10, 1 (cheese - IV, 22, 1, 1).

${ }^{69}$ Oribasius, Collectiones medicae, III, 6, 1, 1-2, 7 (cheese - III, 6, 2, 6).

${ }^{70}$ Oribasius, Collectiones medicae, XIV, 60, 1, 1 - 2, 49 (cheese - XIV, 60, 2, 41-42); OrIbasius, Libri ad Eunapium II, 23, 1, 1-32 (cheese - II, 23, 1, 26); OrIBAsIUs, Synopsis ad Eustathium filium, II, 50, 1, 1-18 (cheese - II, 50, 1, 15-16).
} 
the line of medical tradition represented by Celsus, since he characterised the product in terms of its therapeutic properties. As a result, it was listed as an emollient ${ }^{71}$, was classified as moderately diaphoretic ${ }^{72}$, said to clear the chest by coughing $^{73}$, and attributed with the ability to evacuate pus from the body ${ }^{74}$. The physical doctor noted only one diet-related quality, namely its capability of supporting digestion $^{75}$.

The analysis presented above indicates that the characterization of milk and dairy products was significantly expanded until the second half of the $4^{\text {th }}$ century. On the other hand, the presented material also proves that none of the statements included in the works of Oribasius implies departure from the rules adopted by the theory presented by Celsus in the $1^{\text {st }}$ century AD.

Having proved a connection between Celsus' findings and the well-established dietetic and pharmacological doctrine represented by the Greek physicians of antiquity and the Byzantine period, it should also be noted that De medicina contains many details regarding the role of dairy products in the feeding patterns of ancient patients as prescribed by their physicians. It should be emphasized that those practical applications of the adopted theory are not only a demonstration of the internal cohesion of Celsus' knowledge, but also relevant material for examination of the eating pattern typical of the Mediterranean up to the first half of the $1^{\text {st }}$ century. Let us now move on to the presentation of data.

Milk (without indication of its type) was for example recommended as an element of diet used in the cases of permanent loss of weight, which was a symptom of a disease called in Latin phthisis ( $\varphi$ í⿴囗⿱一一) in Greek). Celsus reveals that adding milk to soups for consumptives, like for example the famous ptisáne ( $\pi \tau \iota \sigma a ́ v \eta)$, called tisana ${ }^{76}$ in the language of Cicero, to spelt flour pulp, and also to a certain starch dish (amulum/amylum in Latin, ä $\mu v \lambda o v$ in Greek $)^{77}$ was a standard therapeutic procedure. The author also added that according to his medical knowledge milk should be completely eliminated if patients suffered from acute fever, thirst

\footnotetext{
${ }^{71}$ Oribasius, Libri ad Eunapium, II, 13, 1, 1-23 (butter - II, 13, 1, 23); OrIBAsIUs, Synopsis ad Eustathium filium, II, 27, 1, 1-6 (butter - II, 27, 1, 6).

${ }^{72}$ Oribasius, Collectiones medicae, XIV, 60, 1, 1 - 2, 49 (butter - XIV, 60, 2, 42); Oribasius, Libri ad Eunapium, II, 23, 1, 1-32 (butter - II, 23, 1, 26); OrIbasius, Synopsis ad Eustathium filium, II, 50, 1, 1-18 (butter - II, 50, 1, 16).

${ }^{73}$ Oribasius, Libri ad Eunapium, II, 17, 1, 1 - 2, 2 (butter - II, 17, 1, 2); Oribasius, Synopsis ad Eustathium filium, II, 39, 1, 1 - 3, 8 (butter - II, 39, 1, 1).

${ }^{74}$ Oribasius, Libri ad Eunapium, II, 12, 1, 1-16 (butter - II, 12, 1, 13); Oribasius, Synopsis ad Eustathium filium, II, 26, 1, 1-3 (butter - II, 26, 1, 3).

${ }^{75}$ Oribasius, Libri ad Eunapium, II, 11, 1, 1-4 (butter - II, 11, 1, 3); Oribasius, Synopsis ad Eustathium filium, II, 25, 1, 1-3 (butter - II, 25, 1, 3).

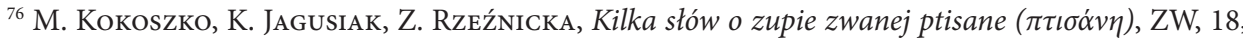
2013, s. 282-292.

${ }^{77}$ Celsus, De medicina, III, 22, 11.
} 
caused by an increase of body temperature, swelling of chest, bleeding or when their urine contained bile $\mathrm{e}^{78}$. On the fourth or fifth day of the treatment, apart from spicy food, the patients were given a cup of broadleaf plantain (Plantago maior L) juice or a teaspoon of white horehound (Marrubium vulgare $\mathrm{L}$ ) juice boiled with honey as a medicament. Terebinth resin (Pistacia terebinthus $\mathrm{L}$ ) cooked with butter and honey were another medicament suitable for this kind of treatment ${ }^{79}$.

Milk was also a product used in curing a condition that was manifested by difficulties with breathing. Its mildest variety was described by the Greeks as $\delta \dot{\sigma} \sigma v_{v o l \alpha}$, the more severe one was called ã $\sigma \theta \mu \alpha$, whereas the most dangerous one was classified as ó $\rho \theta \dot{\pi} \pi v o a^{80}$. The procedure recommended by Celsus included bloodletting and facilitation of intestinal cleansing through consumption of milk and, when necessary, provoking excretion through enemas ${ }^{81}$.

Milk was also essential as a foodstuff given to patients suffering from throat ulcers $^{82}$. In turn, food that was spicy or coarse in texture was avoided. Instead, honey, lentil, spelt wheat soup called tragum, milk, the aforementioned barley soup known as tisana, fatty meat and leek decoction were recommended ${ }^{83}$. Cough was also a definitely very frequent condition. Several varieties of this ailment were distinguished (mainly productive and non-productive one ${ }^{84}$. Regardless of the type of this affliction, Celsus recommended travelling, especially sea journeys ${ }^{85}$. Living near the coast and swimming in the sea were also favourable. When it comes to food, the author recommended both mild and spicy products. Among the former ones, Celsus suggested consuming mallow and young nettle tips. Among the spicy ones, he listed milk cooked with garlic, soups with asafoetida (laser) or leek (cut into pieces), soft-boiled eggs with sulphur and water to drink (and then either water or wine on alternate days) ${ }^{86}$.

On the other hand, when a patient suffered from spleen disease which was manifested by its augmentation, swelling on the left side, tension of abdomen part, oedema of the legs and other symptoms, milk and cheese ${ }^{87}$ (also sweets)

\footnotetext{
${ }^{78}$ Celsus, De medicina, III, 22, 10.

${ }^{79}$ Celsus, De medicina, III, 22, 13.

${ }^{80}$ Celsus, De medicina, IV, $8,1$.

${ }^{81}$ Celsus, De medicina, IV, 8, 2.

${ }^{82}$ In interiore vero faucium parte exulceratio - Celsus, De medicina, IV, 9, 1.

${ }^{83}$ Celsus, De medicina, IV, 9, 3.

${ }^{84}$ Celsus, De medicina, IV, 10, 1.

${ }^{85}$ Aióra - a form of medical procedure. Cf. М. Кокоszко, Medycyna bizantyńska na temat aiora ( $\alpha i \omega ́ \rho \alpha)$, czyli kilka słów o jednej z procedur terapeutycznych zastosowanych w kuracji cesarza Aleksego I Komnena (na podstawie pism medycznych Galena, Orybazjusza, Aecjusza z Amidy i Pawła z Eginy, [in:] Cesarstwo bizantyńskie. Dzieje, religia, kultura. Studia ofiarowane Profesorowi Waldemarowi Ceranowi przez uczniów na 70-lecie Jego urodzin, ed. P. KRUPCZYŃsKI, M.J. LESZKA, Łask-Łódź 2006, p. 87-111.

${ }^{86}$ Celsus, De medicina, IV, 10, 4.

${ }^{87}$ It is the only Celsus' medical recommendation, wchich expressis verbis refers to cheese.
} 
were completely eliminated from the eating pattern ${ }^{88}$. Instead, sour substances were recommended in such cases, especially spicy wine vinegar or vinegar with sea onion (Squilla maritima L), drunk slowly with small sips. Salted fish, olives in strong brine, salad, endive with vinegar, beetroots with mustard etc. were also prescribed, along with trotters (ungulae), chaps (rostra), non-fattened poultry (aves macrae) and game ${ }^{89}$.

The case was different when the patients experienced chronic colic. When they

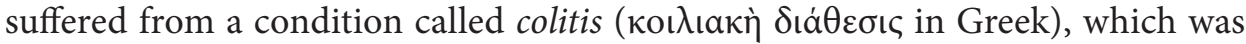
manifested by stomachache, inability to excrete gases cumulated in the intestines, constipation, a drop in the temperature of the extremities of patient's body and difficulties with breathing ${ }^{90}$, the pain was alleviated by warm compresses, triggering vomiting (in order to empty the stomach) and cupping therapy in the area of abdomen and hips ${ }^{91}$. In order to provoke purgation, patients were administered milk without any additions or milk mixed with water on a one-for-one basis. One of Celsus' remarks is particularly interesting as far as the possibility to determine the intake of milk is concerned. He wrote that patients were given (probably on a daily basis) two to three cups (cyathi) of milk and, if necessary, the same amount of milk mixed with water (1:1). One cup, that is cyathus, contained 42 cubic centimetres, which equals around $0.042 \mathrm{l}$, so four cyathi would be equal to a daily dose of milk of about $0.170 \mathrm{l}$ (less than a standard glass). We need to remember that such an amount was prescribed for a particular case of disease (in order to provoke purgation), so it can be assumed that standard consumption was smaller. It was also believed that excretion of gases would be easier when the pressure in the intestines increases, so ground garlic was added to milk. Apart from this, aíwpa, e.g. in the form of sea journeys, rubbing with the use of olive oil with soda, cleansing with warm water, mustard plasters (which caused skin reddening, the

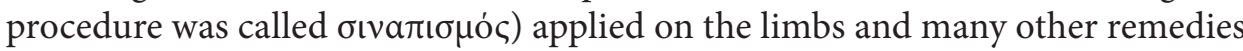
were also recommended ${ }^{92}$.

Milk was also used in diets for the therapy of eye disorder. Celsus wrote that ulcers on eyeballs and eyelids were typical of eye inflammation. In order to eliminate them people would use enemas, go on a diet requiring limitation of food (starvation) and they also drank milk. According to the author, it was supposed to neutralise pungent juices that were responsible for the disease ${ }^{93}$. Milk was also

\footnotetext{
${ }^{88}$ Celsus, De medicina, IV, 16, 1.

${ }^{89}$ Celsus, De medicina, IV, 16, 2. On the dangers of consuming the milk cf. K. Albala, Milk: Nutritious and Dangerous, [in:] Milk..., p. 19-30; F. BLANk, Milk-borne Diseases: An Historic Overview and Status Report, [in:] Milk..., p. 81-85; H. Morrow Brown, The Health Hazards of Milk, [in:] Milk..., p. 259-267.

${ }^{90}$ Celsus, De medicina, IV, 19, 1.

${ }^{91}$ Celsus, De medicina, IV, 19, 2.

${ }^{92}$ Celsus, De medicina, IV, 19, 3.

${ }^{93}$ Celsus, De medicina, VI, 10.
} 
mentioned with regard to the diet of patients suffering from phthirisis ( $\varphi \theta \varepsilon ı$ ia in Greek). The author wrote that this ailment (usually attacking patients who did not care about hygiene) was characterized by lice appearing in the eyelashes and pus of acrid nature coming out of the eye. If the ulcers appeared on the eyeballs, the pus could even lead to loss of vision. Patients were given an enema, their hair was cut and their head was rubbed. Fasting, active walks, mouthwash with mulsum (boiled down with catmint and figs), warm baths and rinsing head with hot water were recommended. Food should have soothing properties. Additionally, patients were told to drink milk and sweet wine, which were supposed to neutralise the acrid character of juices that were produced during this disease $\mathrm{e}^{94}$.

De medicina also contains many tips referring to milk as a simple therapeutic substance and as an ingredient of complex medicaments. Let us start with a conclusion that Celsus' work teaches us that the medicamentum of our interest was applied both internally and externally. Accordingly, when reading De medicina, we learn that milk was considered to be an antidote, especially with regard to mild poisons. For example, it was administered (without any additions) in the case of cantharidin

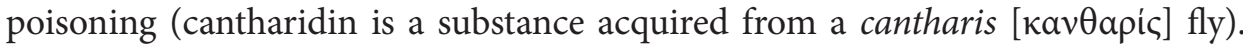
Another method applied in order to help the patient was using allheal, that is panaces (Ferula galabnifera Mill) ground with milk or administering galbanum (juice made of the aforementioned plant) dissolved in wine ${ }^{95}$. In the case of black henbane (Hyoscyamus niger L) poisoning, drinking any type of milk (but especially donkey milk) or hot wine with honey (that is mulsum $)^{96}$ was recommended.

Milk was classified by Celsus as a product used as a mouthwash and gargle. The same effect was demonstrated by (probably watered-down) barley soup (tisana) and bran gruel ${ }^{97}$. The drink of our interest in such a form was used in the final stage of tonsillitis, but bran stock could also be used for the same purpose ${ }^{98}$. It is also worth adding that the only remark presented by Celsus with regard to therapeutic properties of cheese applies to oral cavity disorders. We learn that aphtae (aphthae in Latin, ä $\varphi \theta a$ in Greek) in children's mouth were removed by applying (probably fresh) cheese mixed with honey on them ${ }^{99}$.

One of the frequent ailments described in Greek and Latin sources was dysentery. Celsus wrote that the patient suffering from this disease was supposed to rest. Special plasters that could stop diarrhoea were put on his stomach and his anus was rinsed with warm water with verbena boiled in it (Verbena officinalis $\mathrm{L})^{100}$.

\footnotetext{
${ }^{94}$ Celsus, De medicina, VI, 6, 15 - 15 b.

${ }^{95}$ Celsus, De medicina, V, 27, 12.

${ }^{96}$ Celsus, De medicina, V, 27, 12 b. Cf. A. Touwaide, La toxicologie dans le De medicina: un système asclépiado-méthodique?, [in:] La Médecine..., p. 211-256.

${ }^{97}$ Celsus, De medicina, V, 22, 9.

${ }^{98}$ Celsus, De medicina, VI, 10, 4.

${ }^{99}$ Celsus, De medicina, VI, 11, 3.

${ }^{100}$ Celsus, De medicina, IV, 22, 2.
} 
People were also given enemas in such a situation. Here, clysters made of thin tisana or milk were described by the author as effective. Moreover, melted animal fat, deer marrow, olive oil, rose oil mixed with butter (another dairy product of our interest) or egg white, as well as many other substances were introduced into the intestines ${ }^{101}$. Themison, as Celsus accounts, even recommended using to this end the brine in which olives were kept. As for the food given to patients, it should have astringent properties ${ }^{102}$.

In gynaecology described by Celsus, milk was used to cure hysteria. Firstly, nightshade fruits (Solanum nigrum L) were dipped in milk and then ground with white wax or deer marrow (mixed with iris oil) or beef suet (or goat suet with rose oil) to produce ointment, which was then put as an emollient on patient's abdomen being hard as a result of the disease (super imum ventrem) ${ }^{103}$. Apart from this, the therapeutic procedure included emptying patient's intestines, which was achieved by means of giving an enema or milk ${ }^{104}$. We also learn that woman's milk was used to produce suppositories to trigger menstruation. In order to make such a medicament, the pulp of a wild cucumber (cucumis silvestris) was ground and mixed with human milk ${ }^{105}$, and then a piece of soft wool saturated with this substance was inserted into the genitals ${ }^{106}$.

Milk was also among the substances used by ancient nephrology. The author of De materia medica claimed that in the case of kidney disorders, patients should rest, sleep on a soft bed, cleanse the intestines regularly (even by means of enemas), take warm baths, avoid cold food and drinks, as well as abstain from salty, sour and hot food ${ }^{107}$. In order to cure the patient of this disease, he was given a mixture made of wild cucumber seed, pine nuts, aniseed and saffron, which were given to him with sweet mulsum wine. However, when pain appeared, an appropriate remedy made of thirty seeds of a squirting cucumber (Ecballium elaterium [L.] A.Rich.), twenty pine nuts, five almonds (nuces Graecae) and a bit of saffron (crocus) was administered. The ingredients were ground and then mixed with milk ${ }^{108}$.

When it comes to external applications, Celsus reveals that joint problems (both concerning upper and lower limbs) occurring in the case of diseases such as

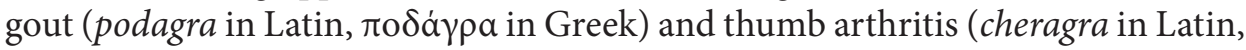
$\chi \varepsilon\llcorner\rho a ́ \gamma \rho a$ in Greek) were cured with the use of donkey milk treated as a sensu stricto medicament. However, it has to be concluded that this medicament was effective only in the initial phase of illness. Nota bene, the same effect was supposed to

${ }^{101}$ Celsus, De medicina, IV, 22, 3.

${ }^{102}$ Celsus, De medicina, IV, 22, 4.

${ }^{103}$ Celsus, De medicina, IV, 27, 1.

${ }^{104}$ Celsus, De medicina, IV, 27, 2.

${ }^{105}$ Celsus, De medicina, V, 21 b, 1.

${ }^{106}$ Celsus, De medicina, V, 21, a.

${ }^{107}$ Celsus, De medicina, IV, 17, 1.

${ }^{108}$ Celsus, De medicina, IV, 17, 2. 
be achieved by avoiding wine, mulsum and sex ${ }^{109}$. In the advanced stage of the disease patients were given the following recommendations: they should take a lot of exercise, visit a hot bath and ferment the sore limb in a medical solution ${ }^{110}$. Sometimes a wet cooling therapy was also used, especially when the temperature of the body areas attacked by the disease was increased ${ }^{111}$. When the pain became so strong that it was impossible to touch the place affected by the disease, it could be soothed by rinsing the affected area with a sponge dipped in hot extract of poppy-head skin or cucumis silvestris ${ }^{112}$. Then, the place was smeared with saffron, poppy juice and sheep milk ${ }^{113}$. The author also added that patients who were aware of the fact that they suffer from seasonal joints ache should try to fend off this danger by a special diet and avoiding excess of dangerous substances in the food. In order to do this, they should use emetics and cleanse their intestines by drinking milk. The author of De medicina also added that the latter method was rejected by Erasistratus in fear of the risk of dangerous juices inflow into the feet in gout. However, Celsus considered the fear as unjustified and suggested that the famous physician was wrong, because the aforementioned remedies resulted in the equal removal of the juices from both upper and lower parts of the body ${ }^{114}$.

Milk was also used as an ingredient of remedies for wounds ${ }^{115}$. Celsus wrote that when uncontrolled tissue growth occurred on the edges of such bodily damage, certain substances supposed to stop this phenomenon were applied. It was achieved by means of applying dry lint (siccum linamentum) or copper scales (squamae) on the affected skin area. When fungation was widespread, corossives were used. After removing the dressing, boxthorn (lycium - Rhamnus infectorius $\mathrm{L}$ ) decoction dissolved in passum wine or in milk was poured over the wound, which was supposed to speed up the process of scarring ${ }^{116}$.

Milk was also an ingredient of medicaments used in ophthalmology. Celsus mentioned that woman's milk was added (in order to alleviate their effect) to eye ointments (or salves) known in Latin as collyrium, and in Greek as ko $\lambda \lambda \dot{v} \rho ı v$. However, the author also indicated that it was used in order to modify the salve known as cycnon (or tephron) ${ }^{117}$ and also to another one known by the name

\footnotetext{
${ }^{109}$ Celsus, De medicina, IV, 31, 1.

${ }^{110}$ Celsus, De medicina, IV, 31, 3-4.

${ }^{111}$ Celsus, De medicina, IV, 31, 5.

${ }^{112}$ Probably another name of squirting cucumber.

${ }^{113}$ Celsus, De medicina, IV, 31, 6.

${ }^{114}$ Celsus, De medicina, IV, 31, 9.

${ }^{115}$ About this issue in the works of Celsus, cf. I. Israelowich, Patients..., p. 96-97.

${ }^{116}$ Celsus, De medicina, V, 26, 30 c.

${ }^{117}$ Cycnon/tephron - made from starch, astragalus and acacia juice, cummis gum, poppy seed juice, rinsed white lead (in Latin: cerussa; in Greek: $\psi(\mu \mu v \dot{\theta} \theta \mathrm{ov})$ and lead monoxide. The ingredients were mixed together with rainwater. In the case specified by Celsus, water was replaced with breast milk
} 
of trygodes ${ }^{118}$. Both those remedies were applied to the eyes in the case of moderate inflammation. Milk (without indication of the animal which gave it) was also mixed with other medicaments within the same group. Thus, in De medicina we read that in the case of acute eye inflammation called proptosis ( $\pi \rho$ ó $\pi \tau \omega \sigma\llcorner\varsigma$ in Greek), which was manifested by swelling that created an impression of eyeballs falling out of the orbits, when loss of vision occurred and pus was coming out of the outer corner of the eye (the one on the temple side), eyeball incision was performed. The aim of the procedure was to create an outlet for the accumulated pus, stop the pain and avoid permanent disfigurement. After the operation, Cleon's or Nileus' kollyrion was applied to the eye, but it was mixed (for the sake of alleviation of its effect) with milk (or with egg) ${ }^{119}$. Moreover, in the case of eye ulcers, Philalethes's kollyrion ${ }^{120}$ mixed with milk ${ }^{121}$ was used.

Woman's milk was added to remedies for ear inflammation, such as the medicament made of Egyptian broad beans (Nelumbium speciosum L) ground with rose oil and myrrh or of bitter almond juice with rose oil and myrrh ${ }^{122}$. It was instilled into the auricula, which was then closed with a tampon so that the fluid could not come out ${ }^{123}$. When the ear got swollen and discharge was flowing out of it, milk (of no specified type) with boxthorn extract was poured into the ear ${ }^{124}$. Interestingly enough, attar and milk were also used in skull surgery. The drops were supposed to help the trephine (modiolus, $\chi 0 เ v \varepsilon ı \kappa^{\prime} \varsigma^{125}$ in Greek) sink into the skull bones, because the fluids reduced friction ${ }^{126}$.

Even though cheese is mentioned rarely in De medicina, and the therapeutic applications of whey could only be guessed from the fragments concerning the purgative properties of milk, Celsus' remarks indicate that butter was an ingredient of many remedies used externally, mainly in the treatment of wounds and

- Celsus, De medicina, VI, 6, 7. Galen also knew about this medicament (De compositione medicamentorum secundum locos, 795, 4-10, vol. XII, [in:] Claudii Galeni opera omnia, ed. C.G. KüHN, vol. XII-XIII, Lipsiae 1826-1827) (cetera: GALEN, De compositione medicamentorum secundum locos), and so did Aetius of Amida (Iatricorum libri, VII, 106, 75-80).

${ }^{118}$ Trygodes made from Castoreum, lycium (boxthorn/lyceum - Rhamnus infectorius L), nard, poppy seed juice, saffron, myrrh, aloe, burned copper, cadmia loam, antimonite, acacia juice and cummis gum - Celsus, De medicina, VI, 6, 8. They are also familiar to Galen - Galen, De compositione medicamentorum secundum locos, 713, 9-10, vol. XII).

${ }^{119}$ Celsus, De medicina, VI, 6, 9 b-c.

${ }^{120}$ Philalethes' Kollýrion - myrrh, poppy seed juice, rinsed lead, loam from Samos, astragalus juice, antimony, starch, rinsed zinc oxide and white lead - Celsus, De medicina, VI, 12.

${ }^{121}$ Celsus, De medicina, VI, 12.

${ }^{122}$ Celsus, De medicina, VI, 7 e.

${ }^{123}$ Celsus, De medicina, VI, 7 c.

${ }^{124}$ Celsus, De medicina, VI, 7, 3 b-4.

${ }^{125}$ Celsus, De medicina, VIII, $3,1$.

${ }^{126}$ Celsus, De medicina, VIII, 3, 3. Cf. I. MAzzini, La chirurgia celsiana nella storia della chirurgia greco-romana, [in:] La Médecine..., p. 135-166. Milk in medical sources of Byzantine period cf. M. Chrone, 'H $\pi \alpha v i \delta \alpha \ldots$, p. 202-209. 


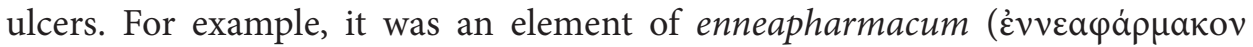
in Greek) ${ }^{127}$, which was used to cleanse wounds. It consisted of wax, milk, suet, resin, myrrh, rose oil, bone marrow (deer, veal or beef), lanolin and butter mixed in equal proportions ${ }^{128}$. Nota bene, in order to remove contamination and fill the wounds created within the tendon (after removing the pus), it was smeared with a less complex mixture, namely butter ground with rose flowers and a bit of honey $^{129}$. Buturum was also referred to as an ingredient of the so-called enchrista $\left(\varepsilon^{\prime \prime} \gamma \chi \rho\left\llcorner\sigma \tau \alpha^{130}\right)\right.$, which were, as Celsus explained, liquid medicaments used to cure ulcers (while the Roman author referred to ulcers created on hard tissues, such as tendons, in his narration). One of the medicaments of this kind consisted of equal parts of butter, veal bone marrow, veal fat, goose schmaltz, wax, honey, terebinth, rose oil and castor oil. If the last but one ingredient was replaced with cypress oil, the medicament became also an emollient, so it helped with calluses ${ }^{131}$. Attention should also be paid to the fragments of Celsus' works which prove that butter was used as an ingredient of remedies for treatment of delicate and sensitive body parts (which were usually protected naturally from contact with the outer world), like for example treatment of meninx damages. The author of De medicina claimed that in order to eliminate swelling (so grave that the meninx was visible and started to come out of the wound, even beyond skull bones), ground lentil or grape vine leaves with fresh butter or goose schmaltz were applied on the area affected by the inflammation ${ }^{132}$.

The treatise also comprises a note that butter was suitable for genitals treatment (both in females and males). Endometritis was often cured with the use of Numenius' medicine. Its ingredients included saffron, wax, butter, goose schmaltz, boiled egg yolks and attar ${ }^{133}$. On the other hand, treatment of male penises (if ulcers on this body part were dry) consisted of rinsing the spot with warm water, and then smearing it with butter mixed with rose oil, lycium barbarum extract or amurca (amurca) mixed with wine. When the exudate appeared, ulcers were rinsed with wine, and then the area affected was covered with a mixture of butter, rose oil, honey and terebinth resin ${ }^{134}$.

\footnotetext{
127 This medicament was well known to Greek medics, e.g. cf. GALEN, De compositione medicamentorum secundum locos, 310, 15 - 311, 5, vol. XIII; Oribasii eclogae medicamentorum, 146, 17, 1-3, [in:] Oribasii collectionum medicarum reliquiae, ed. I. RAEDER, vol. IV, Lipsiae-Berolini 1933 (cetera: Oribasius, Eclogae medicamentorum); Aetius of Amida, Iatricorum libri, XVI, 82, 16-19; PAUL of Aegina, Epitome, VII, 24, 6, 1-3.

${ }^{128}$ Celsus, De medicina, V, 19, 10.

${ }^{129}$ Celsus, De medicina, V, 26, 30.

${ }^{130}$ This term is used by e.g. Oribasius - Oribasius, Libri ad Eunapium, III, 34, 4, 4.

${ }^{131}$ Celsus, De medicina, V, 23, 3.

${ }^{132}$ Celsus, De medicina, VIII, 4, 19.

${ }^{133}$ Celsus, De medicina, V, 21, 4.

${ }^{134}$ Celsus, De medicina, VI, 18, 2 c. Butter in medical sources of Byzantine period, cf. M. Chrone, 'H $\pi \alpha v i \delta \alpha \ldots$, p. 209-217.
} 
The scope of data contained in the catalogue of diseases and treatments with the use of milk and milk-derived products is yet another confirmation of the conclusion that has already been presented, namely that the ancient galactology had developed significantly before De medicina was written. Nevertheless, it has to be emphasized that the lists of analogous diseases and similar applications of milk (and milk-derived products) in the treatment of such diseases can be found in many treatises written by the Asclepiads of Antiquity, and then of the early Byzantine Empire ${ }^{135}$. In order to show the position of Celsus' therapeutics more expressly, it would be proper to refer to, as in the case of dietetic and pharmacological characterizations, the selected parallels recorded by other authors who were also interested in this subject. These are, first of all, the work of Pliny representing Latin literature and scholarship (the author was familiar with Celsus' treatise $\left.{ }^{136}\right)$, and the works of Dioscorides, who was chosen as the representative of the Greek medical output. Both treatises were created in the period relatively close to Celsus, so they constitute a perfect proof of galactology expertise level in the second half of the $1^{\text {st }}$ century.

Our comparative analysis shall be commenced with the issue of using milk for rescuing people who were poisoned. Pliny wrote quite a lot about the effectiveness of milk as an antidote, and when doing so he expressis verbis listed poisonings caused by administration of cantharidin to a patient. The methods of counteracting such a poisoning were earlier referred to by Celsus. Apart from the treatment mentioned, the author of Historia naturalis described milk as a medicine used in curing poisonous snakes' bites or in the case of drinking venom derived from

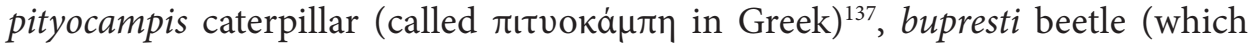
was referred to by the Greeks as ßovं $\rho \eta \sigma \tau ı)$, salamander, as well as consuming other substances potentially dangerous for human beings ${ }^{138}$. It should be mentioned here that Dioscorides confirms this effect of milk and he mentions almost the same examples as Pliny ${ }^{139}$.

We also discover the convergence of information provided by those three authors in the case of treatment of throat complaints. Just like Celsus did before him, the author of Historia naturalis described the use of milk as gargle in the

\footnotetext{
${ }^{135} \mathrm{Cf}$. analogies of the enneapharmacum. Unfortunately, this topic is too complex, and will not be elaborated within this study. I will focus on it in the future.

${ }^{136}$ Pliny points to Celsus as a source for book XV. Cf. C.M. Oser-Grote, op. cit., col. 189.

${ }^{137}$ Thaumetopoea pityocampa.

${ }^{138}$ PlinY, Historia naturalis, XXVIII, 33, 128-129.

${ }^{139}$ Dioscorides, De materia medica, II, 70, 5, 1-4 (cantharidin - II, 70, 5, 2). Also in the later sources we read about the detoxifying effect of milk. E.g. we know from Oribasius that Rufus of Ephesus claimed that cow or goat milk (as well as chicken broth) were recommended as enemas for those poisoned by black henbane (Hyoscyamus niger L) - Oribasius, Collectiones medicae, VIII, 24, $24,1-2$.
} 
case of throat ulcers ${ }^{140}$, whereas Dioscorides stated that cow milk was particularly effective with regard to irritation of oral cavity and tonsils ${ }^{141}$.

In the case of dysentery treatment, in which the author of De medicina also recommended this product, Pliny listed milk several times (both fresh and boiled with stones) as a medicament used in the form of enema ${ }^{142}$, describing sheep milk as the most effective one with regard to this disease ${ }^{143}$. On the other hand, Dioscorides, even though he did not quote the name of the condition in question, claimed in his characterization of dairy products that boiled milk (using the same method as described by the author of Historia naturalis) was used as an enema in the case of digestive tract disorders ${ }^{144}$.

Furthermore, fresh milk was considered by Pliny to be a good remedy for colic, and in such cases it was also used as an enema ${ }^{145}$. Even though Dioscorides did not refer expressis verbis to this condition in book II of De materia medica, he stated that milk (which became less carminative once boiled), reduced by half, was suitable for treating internal irritation and combating inflow of vicious juices into the digestive tract (коเ $\lambda i \alpha)^{146}$. On the other hand, in Euporista vel de simplicibus medicinis he expressis verbis recommends starch cooked with milk as appropriate for patients suffering from colic $^{147}$.

As we have already mentioned, the author of De medicina draws the reader's attention to the fact that milk was used as one of the medicaments in gynaecology. Pliny also acknowledges the position of milk as a remedy for women diseases

\footnotetext{
${ }^{140}$ Pliny, Historia naturalis, XXVIII, 33, 129.

${ }^{141}$ Dioscorides, De materia medica, II, 70, 5, 4-6. Identical applications can be found in later literature. For example, Galen suggested using milk as a mouthwash or applying it for any inflammations of oral cavity. Milk soothed afflictions of tonsils and it was applied in cases of tonsillitis - GaLEN, De simplicium medicamentorum temperamentis ac facultatibus, 268, 11-18, vol. XII. In turn, Oribasius advised donkey, cow or goat milk mouthwash. He also suggested preparing a decoction from olive and plane leaves that were boiled in vinegar. This malady has been also treated with dry fillings of patina that formed on iron, and pomegranate flower - ORIBAsIUs, Eclogae medicamentorum, 18, $1,1-2,6$ (milk-18,1,1).

${ }^{142}$ PLINY, Historia naturalis, XXVIII, 33, 128.

${ }^{143}$ Sheep milk in mentioned twice. Other reference cf. PLINY, Historia naturalis, XXVIII, 33, 130.

${ }^{144}$ Dioscorides, De materia medica, II, 70, 2, 7-8. As an analogy we suggest Galen's discourse. He wrote that, as for the therapeutical properties of curd, it is an effective cure for dysentery and all the other afflictions resulting from the excess of gastric juices cumulated inside the stomach - GALEN, De simplicium medicamentorum temperamentis ac facultatibus, 267, 1-2, vol. XII. In $4^{\text {th }}$ century Oribasius advised enemas of lukewarm milk or starched milk. To each of these enemas, a myrt, rose, pomegranate pod, lentil or wild pomegranate flower decoction was also added - OrIBAsIUs, Eclogae medicamentorum, 54, 16, 1 - 17, 1 (milk - 54, 16, 3).

${ }^{145}$ PLINY, Historia naturalis, XXVIII, 33, 128.

${ }^{146}$ Dioscorides, De materia medica, II, 70, 3, 3-5.

${ }^{147}$ Pedanii Dioscuridis Anazarbei euporista vel de simplicibus medicinis, II, 51, 2, 1-2, [in:] Pedanii Dioscuridis Anazarbei de materia medica libri quinque, ed. M. Wellmann, vol. III, Berlin 1914 (cetera: DiosCorides, Euporista vel de simplicibus medicinis).
} 
(he considered sheep milk to be particularly useful in gynaecological therapies ${ }^{148}$ ) and indicates this product as a substance used in intrauterine wash ${ }^{149}$. This last application is confirmed with the words of the author of De materia medica ${ }^{150}$.

Apart from this, Pliny (just like Celsus before him) described milk as a medicament administered to the patients suffering from nephritis and cystitis ${ }^{151}$, which is fully confirmed by Dioscorides ${ }^{152}$. It was probably used in the form of washes, as excessive consumption of this substance could lead to kidney stones ${ }^{153}$.

When it comes to the analogy with curing rheumatism treatment, it has to be indicated that the author of Historia naturalis, just like Celsus, determined an important role for donkey milk as an element of gout and thumb arthritis treatment ${ }^{154}$, whereas Dioscorides mentioned woman's milk as an element of therapy for the former condition ${ }^{155}$. What is more, Pliny recommended milk as a solution for all tendon conditions ${ }^{156}$, whereas Dioscorides came to the conclusion that the best remedy for hard tissue disorders would be human milk ${ }^{157}$.

It comes as no surprise, then, that Celsus mentioned application of milk in remedies for wounds, as this can be expressly derived from the characterization of this drink and food as a dispersant and soothing substance that he adopted in his work. Pliny also considered milk to be so soothing and delicate that it was suitable even in the cases of internal organ damage ${ }^{158}$, whereas Dioscorides mentioned numerous external applications of milk in the treatment of external itchy irritation $(\kappa \nu \eta \sigma \mu o i)^{159}$.

\footnotetext{
${ }^{148}$ PLINY, Historia naturalis, XXVIII, 33, 130.

${ }^{149}$ PlinY, Historia naturalis, XXVIII, 33, 128.

${ }^{150}$ Dioscorides, De materia medica, II, 70, 5, 11-12. On the other hand, Galen of Pergamon claimed that milk may be injected into an ulcerated uterus. It could be applied on its own or mixed with other soothing remedies. It is also used in the treatment of proctitis (caused by acrid juices and inflammations), and painful anal corrugation - GALEN, De simplicium medicamentorum temperamentis ac facultatibus, 268, 2-6, vol. XII. For example Oribasius recommended wolfberry decoction with milk in vaginal discharge problems - OriBAsIUs, Libri ad Eunapium, IV, 111, 1, 1 - 11, 2 (milk - IV, 111, 10, 4-5).

${ }^{151}$ PLINY, Historia naturalis, XXVIII, 33, 125.

${ }^{152}$ Dioscorides, De materia medica, II, 70, 2, 10.

${ }^{153}$ GALEN, De alimentorum facultatibus, 686, 16 - 687, 4. Obviously, milk rinses were allowed in treatment of even the most delicate body parts, which was shown earlier, cf. the gynaecological use of milk in the works of Galen.

${ }^{154}$ PLINY, Historia naturalis, XXVIII, 33, 125.

${ }^{155}$ Dioscorides, De materia medica, II, 70, 6, 5.

${ }^{156}$ PLINY, Historia naturalis, XXVIII, 33, 128.

${ }^{157}$ Dioscorides, De materia medica, II, 70, 6, 6.

${ }^{158}$ PLINY, Historia naturalis, XXVIII, 33, 128.

${ }^{159}$ Dioscorides, De materia medica, II, 70, 5, 11-12. Galen suggested the use of fresh cheese in order to cicatrize wounds - GALEN, De simplicium medicamentorum temperamentis ac facultatibus, 270, $13-272$, 2, vol. XII. He also mentioned the specific kind of this product, invented in his homeland

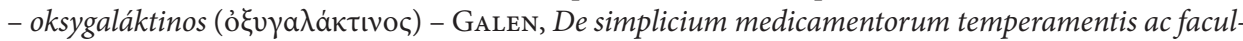
tatibus, 272, 2-5, vol. XII.
} 
As for the universality of milk applications in ophthalmology that we encounter in the fragments of De medicina, Pliny recommended using it (mixed with ground sesame) to rinse the eyes ${ }^{160}$, whereas the author of De materia medica described its ${ }^{161}$ usefulness for treatment of eyes bloodshot as a result of strikes ${ }^{162}$. Nota bene, in eye therapy (in the case of inflammation and extravasation) he especially recommended fresh cheese used as poultice ${ }^{163}$. Ultimately, it is no wonder that Celsus provided for the use of milk as far as ear treatment is concerned, as we already know that he acknowledged the application of milk for sensitive body parts. Similar views were confirmed by Pliny and Dioscorides ${ }^{164}$.

When it comes to butter and its use in medicine known to Celsus, the characterization of buturum as presented in Historia naturalis shows that (despite lack of specification of particular therapeutic applications) the Latin author of the work considered it to have exactly the same effect as the one that was required from the medicaments the recipes for which were presented by Celsus. Pliny provided the reader with the following characterization of butter: „Natura eius [buturi] est adstringere, mollire, replere, purgare". This statement proves that, according to the theory known to Pliny, the fat in question was classified as a product of astringent, softening, filling and cleansing properties ${ }^{165}$. Therefore, it could be used in the treatment of wounds and ulcers. Dioscorides presents this matter in an almost identical way ${ }^{166}$, pointing to the same application that can be found in the work of Celsus, namely curing hard tissue damage, especially if pus was excreted from it ${ }^{167}$.

\footnotetext{
${ }^{160}$ Pliny, Historia naturalis, XXVIII, 33, 130.

${ }^{161}$ When combined with frankincense.

${ }^{162}$ Dioscorides, De materia medica, II, 70, 6, 3-4.

${ }^{163}$ Dioscorides, De materia medica, II, 71, 1, 5-6. Galen, in De compositione medicamentorum secundum locos, listed more than twenty ways of using milk in the treatment of the sight organ. To show the parallel between him and Celsus, it suffices to mention the recommendation to instil milk, apart from fenugreek and egg white brew, in eye problems referred to as ofthalmía (ỏ $\varphi \theta \alpha \lambda \mu \dot{\alpha} \alpha$ ), in order to alleviate the pain - GALEN, De compositione medicamentorum secundum locos, 711, 6 - 714, 11, vol. XII (milk - 712, 10, vol. XII). Two centuries later Oribasius said that in the case of a small foreign body in the eye, it ought to be washed with water or milk. Those objects that got stuck deeper were taken out with small pincers. If the foreign body remained under the eyelid, it was removed after the eyelid was pulled away, and the eye was washed with milk afterwards - Oribasıus, Libri ad Eunapium, IV, 31, 1, 1 - 4, 2 (milk - IV, 31, 1, 1; IV, 31, 4, 2).

${ }^{164}$ Cf. above for Pilinius' and Dioscorides' ophthalmology. It is worth mentioning that this therapy was well known, and Oribasius used to quote the words of Antyllos ( $2^{\text {nd }}$ century AD), who recommended instilling the poppy seed juice mixed with milk (or water) into one's ear - OrIBAsIUs, Collectiones medicae, $\mathrm{X}, 35,2,1-2$.

${ }^{165}$ PlinY, Historia naturalis, XXVIII, 33, 134.

${ }^{166}$ The author claims, analogically do Pliny, that butter is used if the doctor needs a filling, cleansing and cicatrizing effect - Dioscorides, De materia medica, II, 72, 2, 5-6. There is no information about its astringency, but we can conclude about it on the basis of the idea of using boútyron in dysentery - DiosCORIDEs, De materia medica, II, 72, 2, 2.

${ }^{167}$ Dioscorides, De materia medica, II, 72, 2, 1-7 (hard tissue - II, 72, 2, 4).
} 
Moreover, butter was an ingredient of remedies for testicles conditions ${ }^{168}$, and (used externally) if applied without any additions, it was an effective cure for endometritis ${ }^{169}$.

Time has come for us to draw some conclusions. The results of the analysis presented in the present discussion depict Celsus' treatise to be competent as far as galactology is concerned, that is well-set in the Greek medical thought. The results of the research have led us to the conclusion that the knowledge about milk was well developed at the moment of compiling the encyclopaedia and it did not undergo significant changes after the author's death. The successors of Celsus' authorities only added to the already existing theory. This doctrine, as physicians generally believed, assumed a double role of milk and milk-derived products, describing and using in therapeutic practice both nutritional and therapeutic functions of dairy. It was sufficiently developed to be recognized as a separate branch in both dietetics and pharmacology.

It is worth emphasizing that due to their factual content, both Celsus' treatise and other medical works containing galactological doctrine have become not only a source of the history of medicine, but also source of information concerning gastronomy, farming and breeding technologies. They also teach us about the consumption patterns of individual dairy products. Information contained in De medicina makes us think that only small amount of milk was consumed. We may also guess that this was a position of milk in the diet of educated town inhabitants to whom De medicina was addressed. They must have belonged at least to the middle class of that time, because they could afford making choices regarding food products - otherwise, Celsus' advice regarding using or rejecting particular food products in the diet recommended by him would have been irrelevant.

The data presented by Celsus show that milk that was fresh (as required by the physician) was hard to obtain. We learn it from the remark stating that milk easily

\footnotetext{
${ }^{168}$ Dioscorides, Euporista vel de simplicibus medicinis, I, 132, 2, 9.

169 Dioscorides, Euporista vel de simplicibus medicinis, II, 73, 2, 1. Consistency in using butter in similar cases should be confirmed by Galen's works. The fat called boútyron was most often employed for treating serious, open sores, for example head injuries. In his treatise, Galen informs that Archigenes $\left(1^{\text {st }}-2^{\text {nd }}\right.$ cent. $\left.\mathrm{AD}\right)$ recommended application of calamintha decoction, álfita barley powder or the aforementioned fat directly into the wound - GALEN, De compositione medicamentorum secundum locos, 520, 7 - 528, 2, vol. XII (quoted recommendations - 523, 9-13, vol. XII; butter - 523, 12 , vol. XII). It is also worth mentioning that butter (as had been also advised by Archigenes mentioned above) was applied as eardrops when ears were injured in a fight - GALEN, De compositione medicamentorum secundum locos, 662, 7 - 663, 17, vol. XII (butter - 662, 15, vol. XII). As it facilitates self-digestion of the fluids which cause localized medical conditions, it was also used in the treatment tissue hardening due to heavy inflammation. For instance, this is how a suppository (the recipe of which Galen borrowed from Charixenus) worked. It was applied in the treatment of "dry" ears. It consisted of lanolin, deer bone marrow, goose fat, Tyrrhenian wax, camphor oil and other ingredients - Galen, De compositione medicamentorum secundum locos, 635, 4 - 640, 3, vol. XII (recipe -635, 8-14, vol. XII; butter - 635, 10, vol. XII).
} 
curdled while it was heated. Therefore, it is no wonder that we usually encounter this partly spoilt (meaning fermented) product described as food belonging to the group of products that easily acidify in the stomach and have purgative properties. Another explanation of purgative effectiveness of milk is lactose intolerance displayed by ancient inhabitants of the Mediterranean.

The dietetic characterizations quoted here also indicate that some methods of extending the useful life of milk were applied, like adding salt to it or heating it. Let us add that fresh milk was easy to obtain in the countryside, but it was more difficult to acquire it in the towns, where most patients cured by the physicians listed by Celsus lived.

The following animals were described as giving milk: donkeys ${ }^{170}$, sheep ${ }^{171}$ and cows $^{172}$. Donkeys, used mainly for transportation purposes, gave little milk, so it could be used primarily for specialist therapies. Its qualities as food were also not valued. Galen described it as watery and almost deprived of fat, which implied that it hardly had any nutritional value from the point of view of dietetics. The case was different with sheep and cow milk, which was highly evaluated as food ${ }^{173}$. It can also be assumed that the opinions of the physician from Pergamon were connected with the preferences of milk consumers, and therefore with the market availability of this product. If this was the case, sheep and cow milk was much more popular than that obtained from donkeys.

When it comes to butter, it did not play a significant dietary role. It is confirmed not only by the factual content of De medicina, but also by the fact that Galen did not describe it in detail in De alimentorum facultatibus (which was his most important diet-related work), but in De simplicium medicamentorum temperamentis ac facultatibus (which is a treatise devoted to simple medicaments) and he referred to it simply as phármakon. On the other hand, Pliny wrote that it was commonly consumed among Barbarians and appreciated by them. Such a statement implies not so much the strangeness of this product in the Mediterranean region, as more limited interest in this product in the Roman world (due to the preferences of the people towards olive oil $)^{174}$.

Celsus provides us with more detail concerning the role of cheese, consumed both in its fresh (short-lasting) and mature (long-lasting) form. The latter was

\footnotetext{
${ }^{170}$ For the subject of these animals and their products cf. M. Chrone, ' $H \pi \alpha v i \delta \alpha \ldots$, s. 90-91, 362, 395-395.

${ }^{171}$ For information on sheep cf. Z. RzeźnICKA, Rola mięsa $w$ diecie $w$ okresie pomiędzy II a VII $w$. wświetle źródeł medycznych, [in:] Dietetyka i sztuka kulinarna..., p. 249-257.

${ }^{172}$ Ibidem, p. 266-279.

${ }^{173}$ GALEN, De alimentorum facultatibus, 681, 11 - 682, 2 (thickness of milk and the species of animals from which it was obtained; donkey milk - 682, 1, vol. VI; sheep milk - 682, 2, vol. VI; cow milk - 681, 14, vol. VI); 684, 7-9, vol. VI (fat content in milk and the species of animals from which it was obtained; donkey milk - 684, 9, vol. VI; sheep milk - 684, 8, vol. I; cow milk - 684, 7, vol. VI). ${ }^{174}$ PlinY, Historia naturalis, XXIII, 35, 133.
} 
suitable for transport, and therefore it could be carried to distant places. It can be assumed that export was cost-effective only in the case of products that could be sold for an appropriate (high) price. Therefore, we expect that the common types of cheese were already known before the moment when De medicina treatise was written down. They were produced in accordance with the established recipes and found consumers even in the distant places. Celsus' reflections also reveal that cheese was a subject of culinary interest. At the same time, data concerning cooking cheese indicate various methods used in order to modify its taste.

Due to the fact that galactology described in De medicina was formed before the $1^{\text {st }}$ century $\mathrm{AD}$, this branch of medicine gives us an insight into the food consumed until that time. The works of Galen, who as a bright observer of life verified with his own experience the theories that reached him from his sources ${ }^{175}$, can also be perceived as the witnesses of those times. Starting from Oribasius, we encounter only repetitions of the established dietetic and pharmacological doctrines regarding milk. This fact questions the credibility of the medical treatises as sources regarding the period contemporary with their authors. However, it is possible that he, as well as Aetius of Amida and Paul of Aegina, wrote down classic doctrines, because changes of the range of available food products and methods of their production were rare or did not happen at all. If so, then the physicians of the early Byzantine Empire simply chose and passed to the next generations such elements of the theory that they considered suitable for their own medical practice.

Eventually, it has to be emphasized that both Celsus' treatise and other medical sources give us a valuable insight into different details of the diet than applications of milk and milk-derived products. Interestingly enough, there are no remarks regarding luxury spices or exotic products in the tips found in De medicina (in the context of milk and milk-derived products). Thus, it is probable that the diet-related details contained there reflect the consumption pattern characteristic for lower and middle social classes. Therefore, Celsus' treatise is a perfect reference to be used in studies concerning daily life of a broad range of the society.

\footnotetext{
${ }^{175}$ When talking about the raw material from which the butter is obtained, he even dared to argue with the authority in the field of materia medica, namely Dioscorides (whose other theories he usually respected). He was surprised that the physician from Anazarbus suggested that butter should be obtained from sheep and goat milk, while he knew it was obtained from cow milk as well, and the name comes from the noun boús ( $\beta$ oṽ $\varsigma$ ) - GALEN, De simplicium medicamentorum temperamentis ac facultatibus, 272, 12-15, vol. XII. Cf. Dioscorides, De materia medica, II, 72, 1, 2-3.
} 


\section{Bibliography}

\section{Sources}

A. Cornelii Celsi quae supersunt, ed. F. MARx, Lipsiae-Berlini 1915.

Aetii Amideni libri medicinales I-VIII, ed. A. OlIvierI, Lipsiae-Berolini 1935-1950.

Galeni De alimentorum facultatibus libri III, [in:] Claudii Galeni opera omnia, ed. D.C.G. KüHN, vol. VI, Lipsiae 1823.

Galeni De compositione medicamentorum per genera libri VII, [in:] Claudii Galeni opera omnia, ed. C.G. KüHN, vol. XIII, Lipsiae 1827.

Galeni de compositione medicamentorum secundum locos libri X, [in:] Claudii Galeni opera omnia, ed. C.G. KüHN, vol. XII-XIII, Lipsiae 1826-1827.

Galeni de simplicium medicamentorum temperamentis ac facultatibus libri XI, [in:] Claudii Galeni opera omnia, ed. D.C.G. KüHN, vol. XI-XII, Lipsiae 1826-1827.

Hippocratis de diaeta, ed. R. Joly, S. ByL, Berlin 1984.

Oribasii collectionum medicarum reliquiae, ed. I. RAEDER, vol. I-IV, Lipsiae-Berolini 1928-1933.

Oribasii eclogae medicamentorum, [in:] Oribasii collectionum medicarum reliquiae, ed. I. RAEDER, vol. IV, Lipsiae-Berolini 1933.

Oribasii Libri ad Eunapium, [in:] Oribasii synopsis ad Eustathium filium et libri ad Eunapium, ed. I. RAEDER, Lipsiae-Berolini 1926.

Oribasii Synopsis ad Eustathium filium, [in:] Oribasii synopsis ad Eustathium filium et libri ad Eunapium, ed. I. RaEDER, vol. VI, 3, Leipzig 1964.

Paulus Aegineta, ed. I.L. Heiberg, vol. I-II, Lipsiae-Berolini 1921-1924.

Pedanii Dioscuridis Anazarbei De materia medica, [in:] Pedanii Dioscuridis Anazarbei De materia medica libri quinque, ed. M. Wellmann, vol. I-III, Berlin 1907-1914.

Pedanii Dioscuridis Anazarbei Euporista vel de simplicibus medicinis, [in:] Pedanii Dioscuridis Anazarbei De materia medica libri quinque, ed. M. Wellmann, vol. III, Berlin 1914.

Pliny, Natural History, transl. H. Rackham, W.H.S. Jones, D.E. EIchHolZ, vol. I-X, London-Cambridge, Mass. 1938-1963.

Rufus d'Ephese, De renum et vesicae morbis, [in:] Oeuvres de Rufus d'Ephese, ed. C. Daremberg, C.E. Ruelle, Paris 1879.

Rufus D'Ephese, De satyriasmo et gonorrhoea, [in:] Oeuvres de Rufus d'Ephese, ed. C. DAREmberg, C.E. Ruelle, Paris 1879.

\section{Secondary literature}

Abdalla M., Milk and its Uses in Assyrian Folklore, [in:] Milk. Beyond the Dairy. Proceedings of the Oxford Symposium on Food and Cookery 1999, ed. H. WALKER, Totnes 2000, p. 9-18.

Albala K., Milk: Nutritious and Dangerous, [in:] Milk. Beyond the Dairy. Proceedings of the Oxford Symposium on Food and Cookery 1999, ed. H. WALker, Totnes 2000, p. 19-30.

Alcock J.P., Milk and its Products in Ancient Rome, [in:] Milk. Beyond the Dairy. Proceedings of the Oxford Symposium on Food and Cookery 1999, ed. H. WALKen, Totnes 2000, p. 31-38.

Amouretti M.-C., Villes et campagnes grecques, [in:] Histoire de l'alimentation, ed. J.-L. Flandrin, M. Montanari, Paris 1996, p. 133-150. 


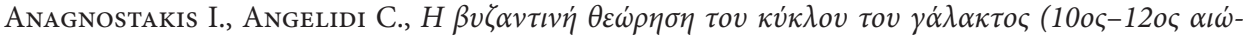

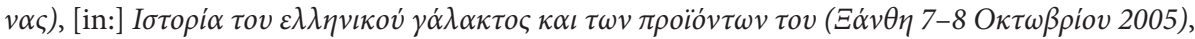
AӨńva 2008, p. 199-209.

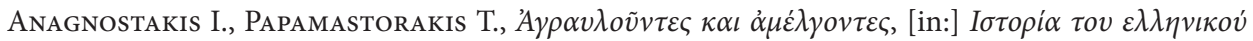

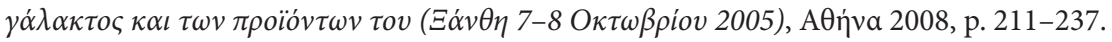

Baldwin B., The Career of Oribasius, AClas 18, 1975, p. 85-97.

Batmanglij N., Milk and its By-products in Ancient Persia and Modern Iran, [in:] Milk. Beyond the Dairy. Proceedings of the Oxford Symposium on Food and Cookery 1999, ed. H. WALKer, Totnes 2000, p. 64-73.

Blank F., Milk-borne Diseases: An Historic Overview and Status Report, [in:] Milk. Beyond the Dairy. Proceedings of the Oxford Symposium on Food and Cookery 1999, ed. H. WALKer, Totnes 2000, p. 81-85.

Bresciani E., Nourritures et boissons de l'Égypte ancienne, [in:] Histoire de l'alimentation, ed. J.-L. Flandrin, M. Montanari, Paris 1996, p. 61-72.

Brunner F.G., Pathologie und Therapie der Geschwülste in der antiken Medizin bei Celsus und Galen, Zurich 1977.

Caseau B., Nourritures terrestres, nourritures célestes. La culture alimentaire à Byzance, Paris 2015.

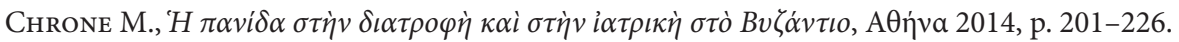

Dalby A., Food in the Ancient World from A to Z, London-New York 2003.

DeICHGRÄBER K., Zur Milchteratpie der Hippokratiker (Epid. VII), [in:] Medizin-Geschichte in unsere Zeit. Festgabe E. Heischkel-Artel und W. Artel, herausg. H.H. Eulner, Stuttgart 1971, p. 36-53.

Déry C.A., Milk and Dairy Products in the Roman Period, [in:] Milk. Beyond the Dairy. Proceedings of the Oxford Symposium on Food and Cookery 1999, ed. H. Walker, Totnes 2000, p. 117-125.

Deuse W., Celsus im Prooemium von "De medicina": Römische Aneignung griechischer Wissenschaft, [in:] Aufstieg und Niedergang der römischen Welt. Geschichte und Kultur Roms im Spiegel der neueren Forschung, herausg. W. HaAse, T. II, Bd. 37, 1, Berlin-New York 1993, p. 819-841.

Diepgen P., Zur Frauenheilkunde im byzantinischen Kulturkreis des Mittelalters. Akademie der Wissenschaften und der Literatur. Abhandlungen der Geistes - und Sozialwissenschaften Klasse, Wiesbaden 1950.

Diller H., Paulos (23), [in:] RE, Bd. XVIII, 4, Stuttgart 1949, col. 2386-2397.

Gabriel R.A., Man and Wound in the Ancient World. A History of Military Medicine from Sumer to the Fall of Constantinople, Washington 2012.

Garzya A., Aetios v. Amida, [in:] Antike Medizin. Ein Lexikon, herausg. K.-H. Leven, München 2005, col. 19-20.

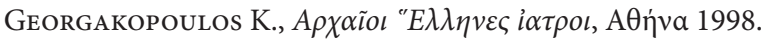

Gossen H., Rufus (18), [in:] RE 2. Reihe, Bd. I, 1, Stuttgart 1914, col. 1207-1212.

Grant M., Oribasios and Medical Dietetics or the Three Ps, [in:] Food in Antiquity, ed. J. Wilkins, D. Harvey, M. Dobson, Exeter 1999, p. 368-379.

Grottanelli C., La viande et ses rites, [in:] Histoire de l'alimentation, ed. J.-L. Flandrin, M. MonTANARI, Paris 1996, p. 117-132.

Hankinson R.J., The Man and His Work, [in:] The Cambridge Companion to Galen, ed. IDEM, Cambridge 2008, p. 1-33.

Healy J.F., Pliny the Elder on Science and Technology, Oxford 2000. 
Hunger H., Die hochsprachliche profane Literatur der Byzantiner, Bd. I, München 1978.

Inм S., Rufus v. Ephesos, [in:] Antike Medizin. Ein Lexikon, herausg. K.-H. Leven, München 2005, col. 759-760.

Israelowich I., Patients and Healers in the High Roman Empire, Baltimore 2015.

Jagusiak K., Кокоszко M., Pisma Orybazjusza jako źródło informacji o pożywieniu ludzi w późnym Cesarstwie Rzymskim, VP 33, 2013, p. 339-357.

JaGusiak K., Кокоszко M., Życie i kariera Orybazjusza w świetle relacji źródłowych, PNH 10, 2011, p. $5-21$.

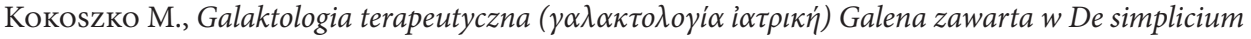
medicamentorum temperamentis ac facultatibus, PNH 14, 2, 2015, p. 5-23.

Kокоszко M., Jagusiak K., Rzeźnicka Z., Introduction. Knowledge of Foods in Medical Sources. Dietetics, Pharmacology and Culinary Art, [in:] IIDEM, Cereals of Antiquity and Early Byzantine Times. Wheat and Barley in Medical Sources (Second to Seventh Centuries AD), transl. K. WodarCZYK, M. ZaKRZEWSKi, M. ZytKa, Łódź 2014, p. 7-28.

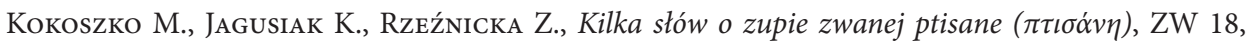
2013, p. 282-292.

Kокоszкo M., Jagusiak K., Rzeźnicka Z., Wstęp. Wiedza o pokarmach w źródłach medycznych. Dietetyka, farmakologia i sztuka kulinarna, [in:] IIDEM, Dietetyka i sztuka kulinarna antyku i wczesnego Bizancjum (II-VII w.), part I, Zboża i produkty zbożowe w źródłach medycznych antyku i wczesnego Bizancjum, Łódź 2014, p. 5-27.

Kокоszко М., Medycyna bizantyńska na temat aiora ( $\alpha i \omega ́ \rho \alpha)$, czyli kilka słów o jednej z procedur terapeutycznych zastosowanych $w$ kuracji cesarza Aleksego I Komnena (na podstawie pism medycznych Galena, Orybazjusza, Aecjusza z Amidy i Pawła z Eginy, [in:] Cesarstwo bizantyńskie. Dzieje, religia, kultura. Studia ofiarowane Profesorowi Waldemarowi Ceranowi przez uczniów na 70-lecie Jego urodzin, ed. P. KrupCzyŃsKi, M.J. LeszKa, Łask-Łódź 2006, p. 87-111.

Kокоszко M., Rola nabiału w diecie późnego antyku i wczesnego Bizancjum (IV-VII w.), ZW 16, 2011, p. 8-28

Kокоszко M., Ryby i ich znaczenie w życiu codziennym ludzi późnego antyku i Bizancjum (IV-VII w.), Łódź 2005.

Kокоszко M., Smaki Konstantynopola, [in:] Konstantynopol - Nowy Rzym. Miasto i ludzie w okresie wczesnobizantyńskim, ed. M.J. LeszKa, T. WolińsKa, Warszawa 2011, p. 471-575.

Kroll W., Plinius (5), [in:] RE, Bd. XXI, 1, Stuttgart 1951, col. 271-439.

Langslow D.R., Celsus and the Makings of a Latin Medical Terminology, [in:] La Médecine de Celse. Aspects historiques, scientifique, and litéraires, Mémoires du Centre Jean Palerne, vol. XIII, ed. G. SABbah, P. Mudry, Saint-Étienne 1994, p. 297-318.

Lehmann H., Au Aëtius Amidenus, Sar 23, 1930, p. 205-206.

Lucia R. De, Oreibasios v. Pergamon, [in:] Antike Medizin. Ein Lexikon, herausg. K.-H. Leven, München 2005, col. 660-661.

Lucia R. de, Oribasio di Pergamo, [in:] A. Garzya, R. de Lucia, A. Guardasole, A.M. Ieraci Bio, M. Lamagna, R. Romano, Medici byzantini. Oribasio di Pergamon. Aezio d'Amida. Alessandro di Tralle. Paolo d'Egina. Leone medico, Torino 2006, p. 21-29.

Marx F., Prolegomena, [in:] A. Cornelii Celsi quae supersunt, ed. F. Marx, Lipsiae-Berlini 1915, p. I-XXV. 
Mazzini I., La chirurgia celsiana nella storia della chirurgia greco-romana, [in:] La Médecine de Celse. Aspects historiques, scientifique, and litéraires, Mémoires du Centre Jean Palerne, vol. XIII, ed. G. Sabbah, P. Mudry, Saint-Étienne 1994, p. 135-166.

МıкоєАјСzyк I., Rzymska literatura agronomiczna, Toruń 2004.

Morrow Brown H., The Health Hazards of Milk, [in:] Milk. Beyond the Dairy. Proceedings of the Oxford Symposium on Food and Cookery 1999, ed. H. WALKer, Totnes 2000, p. 259-267.

Nutton V., Ancient Medicine, London-New York, 2013.

Nutton V., From Galen to Alexander. Aspects of Medicine and Medical Practice in Late Antiquity, DOP 38, 1984, p. 1-14.

Nutton V., Galen and the Traveler's Fare, [in:] Food in Antiquity, ed. J. Wilkins, D. Harvey, M. Dobson, Exeter 1999, p. 359-370.

Oser-Grote C.M., Celsus, [in:] Antike Medizin. Ein Lexikon, herausg. K.-H. Leven, München 2005, col. 189-191.

Perry C., Medieval Arab Dairy Products, [in:] Milk. Beyond the Dairy. Proceedings of the Oxford Symposium on Food and Cookery 1999, ed. H. WALKer, Totnes 2000, p. 275-277.

Pormann P., Paulos v. Aigina, [in:] Antike Medizin. Ein Lexikon, herausg. K.-H. Leven, München 2005, col. 681-682.

Pormann P., The Oriental Tradition of Paul of Aegina's Pragmateia, Leiden 2004.

Riddle J.M., Dioscurides on Pharmacy and Medicine, Austin 1985.

RzeźNICKa Z., Rola mięsa w diecie w okresie pomiędzy II a VII w. w świetle źródet medycznych, [in:] Dietetyka i sztuka kulinarna antyku i wczesnego Bizancjum (II-VII w.), cz. II, Pokarm dla ciała i ducha, ed. M. Кокоszко, Łódź 2014, p. 213-447.

Scarborough J., Early Byzantine Pharmacology, DOP 38, 1984, p. 213-232.

Schultze C.F., Aulus Cornelius Celsus - Arzt oder Laie? Autor, Konzept und Adressaten der De medicina libri octo, Trier 1999.

Sconocchia S., Aspetti della lingua di Celso, [in:] La Médecine de Celse. Aspects historiques, scientifique, and litéraires, Mémoires du Centre Jean Palerne, vol. XIII, ed. G. Sabbah, P. Mudry, Saint-Étienne 1994, p. 281-296.

Sideras A., Einleitung, [in:] Rufus Ephesius, De renum et vesicae morbis, ed. A. Sideras, Berlin 1977, p. 58-69.

Sideras A., Rufus von Ephesos und sein Werk im Rahmen der antiken Medizin, [in:] Aufstieg und Niedergang der römischen Welt. Geschichte und Kultur Roms im Spiegel der neueren Forschung, herausg. H. Temporini, W. HaAse, T. II, Bd. 37, 2, Berlin-New York 1994, p. 1077-1253.

Soler J., Les raisons de la Bible: règles alimentaires hébraïques, [in:] Histoire de l’alimentation, ed. J.-L. Flandrin, M. Montanari, Paris 1996, p. 73-84.

Spanò Giammellaro A., Les Phéniciens et les Carthaginois, [in:] Histoire de l'alimentation, ed. J.-L. Flandrin, M. Montanari, Paris 1996, p. 85-99.

Stamatu M., Dioskurides, [in:] Antike Medizin. Ein Lexikon, herausg. K.-H. Leven, München 2005, col. 227-229.

Stol M., Milk, Butter and Cheese, BSA 7, 1993, p. 99-113.

Thomssen H., Рroвst C., Die Medizin des Rufus von Ephesos, [in:] Aufstieg und Niedergang der römischen Welt. Geschichte und Kultur Roms im Spiegel der neueren Forschung, herausg. H. Temporini, W. HaAse, T. II, Bd. 37, 2, Berlin-New York 1994, p. 1254-1292. 
Touwaide A., La toxicologie dans le De medicina: un système asclépiado-méthodique?, [in:] La Médecine de Celse. Aspects historiques, scientifique, and litéraires, Mémoires du Centre Jean Palerne, vol. XIII, ed. G. SABbah, P. Mudry, Saint-Étienne 1994, p. 211-256.

Wellmann M., Dioskurides, [in:] RE, Bd. V, Stuttgart 1905, col. 1131-1142.

Wyнs K., Die Milch im Kultus der Griechen and Römer, Giessen 1914.

\begin{abstract}
Milk was a very significant food product in the Mediterranean. The present study is not

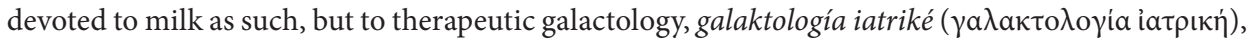
a version of which is extant in De medicina penned by a Roman encyclopaedist called Celsus. The author places milk and milk-derived products among therapeutic substances, indicates the methods of processing such substances, and also provides the readers with details on dietary and pharmacological characteristics of dairy foods as well as indicating their place in a number of cures.

It is necessary to pay attention to the fact that the characterizations of milk and dairy products with regard to their dietary properties and application as phármakon ( $\dot{\alpha} \rho \mu \kappa o v$ ) are not an exclusive feature of De medicina, but they are regularly mentioned not only in medical works, such as $D e$ diaeta $I-I V$, teachings of Dioscorides, extant fragments penned by Rufus of Ephesus, Galen, Oribasius, Aetius of Amida and Paul of Aegina, but also in Historia naturalis by Pliny. This is a clear sign that milk was considered to be significant from the medical point of view and was as such very interesting both for the medical profession and for general public. Therefore De medicina appears as a typical work, and details contained in it are simply a testimony of the evolution of the doctrine that was already present in De Diaeta $I-I V$ and later developed by the most prominent physicians.
\end{abstract}

Keywords: Celsus; history of medicine; history of pharmacology; milk; diary products.

Maciej Kokoszko

Uniwersytet Łódzki

Wydział Filozoficzno-Historyczny

Instytut Historii

Katedra Historii Bizancjum

ul. Kamińskiego 27 a

90-219 Łódź, Polska/Poland

mkokoszko@komanador.pl

Jolanta Dybała

Uniwersytet Jana Kochanowskiego

Filia w Piotrkowie Trybunalskim, Biblioteka

ul. J. Słowackiego 114/118

97-300 Piotrków Trybunalski, Polska/Poland j.dybala@vp.pl 